San Jose State University

SJSU ScholarWorks

Master's Theses

Master's Theses and Graduate Research

1997

\title{
The relationship between water motion and rhodolith movement in the southwestern Gulf of California, Mexico
}

Elizabeth Case Marrack

San Jose State University

Follow this and additional works at: https://scholarworks.sjsu.edu/etd_theses

\section{Recommended Citation}

Marrack, Elizabeth Case, "The relationship between water motion and rhodolith movement in the southwestern Gulf of California, Mexico" (1997). Master's Theses. 1514.

DOI: https://doi.org/10.31979/etd.xg2c-putc

https://scholarworks.sjsu.edu/etd_theses/1514

This Thesis is brought to you for free and open access by the Master's Theses and Graduate Research at SJSU ScholarWorks. It has been accepted for inclusion in Master's Theses by an authorized administrator of SJSU ScholarWorks. For more information, please contact scholarworks@sjsu.edu. 


\section{INFORMATION TO USERS}

This manuscript has been reproduced from the microfilm master. UMI films the text directly from the original or copy submitted. Thus, some thesis and dissertation copies are in typewriter face, while others may be from any type of computer printer.

The quality of this reproduction is dependent upon the quality of the copy submitted. Broken or indistinct print, colored or poor quality illustrations and photographs, print bleedthrough, substandard margins, and improper alignment can adversely affect reproduction.

In the unlikely event that the author did not send UMI a complete manuscript and there are missing pages, these will be noted. Also, if unauthorized copyright material had to be removed, a note will indicate the deletion.

Oversize materials (e.g., maps, drawings, charts) are reproduced by sectioning the original, beginning at the upper left-hand corner and continuing from left to right in equal sections with small overlaps. Each original is also photographed in one exposure and is included in reduced form at the back of the book.

Photographs included in the original manuscript have been reproduced xerographically in this copy. Higher quality 6" $\times 9$ " black and white photographic prints are available for any photographs or illustrations appearing in this copy for an additional charge. Contact UMI directly to order.

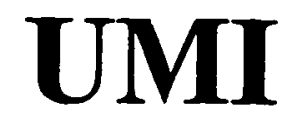

A Bell \& Howell Information Company 



\title{
THE RELATIONSHIP BETWEEN WATER MOTION AND RHODOLITH MOVEMENT IN THE SOUTHWESTERN GULF OF CALIFORNIA, MEXICO
}

\author{
A Thesis Presented to the Faculty \\ of \\ Moss Landing Marine Laboratories
}

In Partial Fulfillment

of the Requirements for the Degree

Master of Science

By

Elizabeth Case Marrack

August, 1997 
OMI Number: 1386215

\section{UMI Microform 1386215}

Copyright 1997, by UMI Company. All rights reserved.

This microform edition is protected against unauthorized copying under Title 17, United States Code.

\section{UMI}

300 North Zeeb Road

Ann Arbor, MI 48103 
(C) 1997

Elizabeth Case Marrack

\section{ALL RIGHTS RESERVED}


APPROVED FOR THE DEPARTMENT OF MARINE SCIENCE

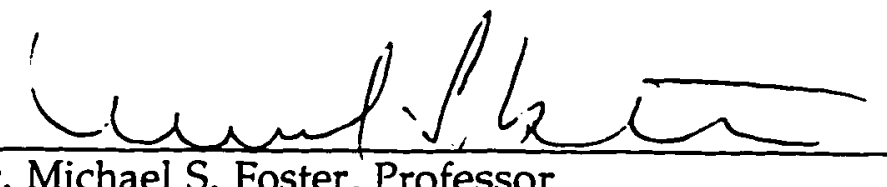

Dr. Michael S. Foster, Professor San Jose State University

William Brenton

Dr. William W. Broenkow, Professor San Jose State University

Ripest Itarison

Dr. Robert Garrison, Professor San Jose State University

APPROVED FOR THE UNIVERSITY

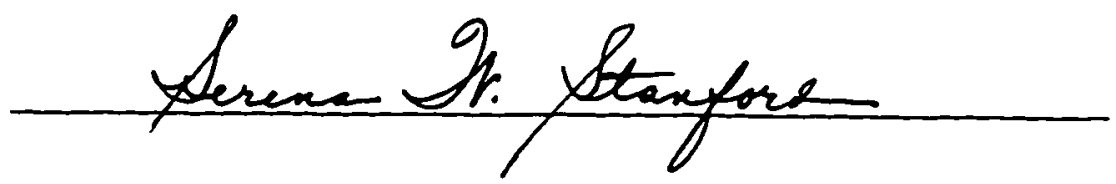




\begin{abstract}
THE RELATIONSHIP BETWEEN WATER MOTION AND RHODOLITH MOVEMENT IN THE SOUTHWESTERN GULF OF CALIFORNIA, MEXICO
\end{abstract}

by Elizabeth Case Marrack

The relationship between water motion and the movement of free living, nodular aggregates of non-geniculate coralline algae known as rhodoliths was quantified in subtidal beds off the southwestern coast of the Gulf of California. One site dominated by wave action and two sites dominated by tidal currents were examined. Manipulative experiments along with simultaneous video and current measurements taken during winter months in 1996 showed that rhodoliths in the shallow margins (4.5 m depths) of wave beds moved frequently due to threshold level velocities from wind propagated waves. During the same period, rhodoliths in the middle and at deep margins of the bed did not move due to attenuation of wave energy with depth. Historical wind records and wave forcasting analysis indicate that shallow rhodolith movement is frequent only in the winter. In deep tidally dominated beds, maximum yearly tidal currents were not sufficient to move rhodoliths. Video and SCUBA surveys show that bioturbation is an important mechanism for rhodolith movement in all beds. Rhodoliths in $12 \mathrm{~m}$ deep current beds and in the deep margins of wave beds may only move occasionally due to bioturbation and severe storms. Rhodolith morphology and distribution appears to be dependent on a combination of factors, especially light, water motion, sedimentation, bottom conditions, bioturbation, and source material. 


\section{ACKNOWLEDGEMENTS}

This project was accomplished due to grants from the David and Lucille Packard Foundation and the Friends of Moss Landing Marine Lab.

Thank you to my thesis advisors Dr. Michael Foster, Dr. William Broenkow, and Dr. Robert Garrison for their guidance, quality instruction, and good humor.

Thank you also to Aldo De la Rosa, Mark Yarborough, and Stephanie Flora without whose technical support I would never have been able to do my project.

Thank you to all the students and staff at Moss Landing Marine Laboratories for a rich experience. To my friends Jonna Engel, Patty Nicely, the BEER PIGS, and the group at Universidad Autonimo Baja California Sur, especially Raphael and Alejandra Riosmena-Rodriguez and Marcos Medina, thank you for all the help and support you have generously provided me.

Lastly, to Dean, you are the best research partner anyone could ever have. 


\section{TABLE OF CONTENTS}

INTRODUCTION

Pages

1

METHODS AND MATERIALS

$\begin{array}{ll}\text { Study Sites } & 8\end{array}$

El Requeson $\quad 8$

Punta Bajo 9

San Lorenzo Channel 10

$\begin{array}{ll}\text { Methods } & 10\end{array}$

Water Motion $\quad 10$

Frequency of Rhodolith Transport 14

Bioturbation $\quad 15$

Regional Distribution $\quad 15$

RESULTS 16

Water Motion 16

El Requeson $\quad 16$

Punta Bajo 19

San Lorenzo Channel 20

Frequency of Rhodolith Movement 20

Bioturbation $\quad 21$

DISCUSSION 24

Factors Affecting Rhodolith Transport 24

Comparison of Rhodolith Threshold Velocities 26

Relationship Between Transport and Rhodolith Morphology 29

Predicted Mechanisms and Frequency of Rhodolith Movement 31

Factors Controlling the Regional Distribution of Rhodoliths in 37 the SW Gulf of California

TABLES

FIGURES

APPENDICES 


\section{LIST OF TABLES}

Pages

Table 1: Observations of rhodolith movement and wind conditions during January and February 1996

Table 2: $\quad$ Statistical comparisons of rhodolith movement between different morphologies and depths

Table 3: $\quad$ Predicted days per month of rhodolith movement in the shallow margin of wave beds

Table 4: Comparison of studies on rhodolith threshold velocities

Table 5: $\quad$ Predicted wave characteristics over $12 \mathrm{~m}$ deep beds 


\section{LIST OF FIGURES}

Pages

Figure 1: Different rhodolith morphologies in the SW Gulf of California

Figure 2: $\quad$ Fossil and living rhodolith beds in the SW Gulf of California

Figure 3: Current speeds and tidal heights at the shallow margin of the El Requeson wave bed

Figure 4: Direction and magnitude of oscillatory wave currents over the El Requeson wave bed

Figure 5: Current speeds and tidal heights at the shallow margin of the El Requeson wave bed

Figure 6: Cumulative displacement of water over time at the El Requeson wave bed

Figure 7: $\quad$ Average period of wind propagated surface waves at $\mathrm{El}$ Requeson

Figure 8: Average significant wave heights of wind propagated waves at El Requeson

Figure 9: Comparison of rhodolith movement with morphology and depth

Figure 10: Current speeds and tidal heights at the Punta Bajo current bed

Figure 11: Cumulative displacement of water over the Punta Bajo and San Lorenzo Channel current beds

Figure 12: Current speeds and tidal heights at the San Lorenzo Channel current bed

Figure 13: Historical wind records from the SW Gulf of California 66

Figure 14: $\quad$ Factors affecting transport of rhodoliths by water motion 67 


\section{LIST OF APPENDICES}

\section{Pages}

Appendix 1: Equation for benthic boundary layer conversions of 68 water speed at differing heights above the seafloor

Appendix 2: Linear wave theory equations 


\section{INTRODUCTION}

Free living, nodular aggregates of non-geniculate coralline algae known as rhodoliths have occurred at least since the Cenozoic in diverse environments on continental shelves around the world. Living beds have been described in tropical reefs (Scoffin et al. 1985, Bosence 1985), temperate fjords and bays (Bosence 1976), and polar regions (Freiwald et al. 1993) from the lowest intertidal to depths over 200 m (Bossellini and Ginsburg 1971, Adey and MacIntyre 1973, Littler et al. 1991). These beds can contribute large amounts of $\mathrm{CaCO}_{3}$ material to nearshore environments (Foster et al. 1996), and are major primary producers in some deep water environments (Littler

et al. 1991). In many of the regions where they are found, rhodoliths provide habitat for growth of a broad range of benthic invertebrates and other foliose algae (Studencki 1979, Scoffin 1985, Steller 1993).

Fossil rhodolith distribution, morphology, and infaunal assemblages have been used as paleoecological indicators (McMaster and Conover 1966, Bosence and Pedley 1982, Minoura and Nakamori 1982, Bosence 1983, Braga and Martin 1988, Freiwald 1991). However, few studies have documented the distribution and ecology of living beds (Bossellini and Ginsburg 1971, Bosence 1976, Prager and Ginsburg 1989, Stellar and Foster 1995), and the effects of the environment on rhodolith growth, form, and composition are debated (Reid and MacIntyre 1989, Stellar and Foster 1995). Until the relationship between environment and rhodolith ecology is clarified, care must be taken in using rhodolith features as geologic indicators. 
The distribution of coralline algae is considered to be primarily controlled by light and temperature (Adey and McKibbon 1970, Adey and Adey 1973, Adey 1973). In more turbid northern waters, rhodoliths are found in relatively shallow areas, but in clearer tropical waters, rhodoliths can occur on offshore banks from 50 to $268 \mathrm{~m}$ depths (Bosence 1983, Littler et al. 1991). Many species of crustose corallines in arctic to temperate waters appear to have depth distributions determined by light (Adey 1971, Adey and Adey 1973). The restriction of some genera to specific latitudes also indicates temperature as an important control (Adey and McKibbon 1973).

For a rhodolith bed to develop, suitable sized grains for algal spore settlement must be present and/or pieces of algal thalli attached to rocky substrate may break off and grow free (Bosence 1985). The cores of rhodoliths are frequently small sediment clasts or pieces of abraided rhodoliths (Adey and MacIbbon 1973, Bosence 1983). Once a bed is established, most recruitment of new individuals is probably by breakage and overgrowth (Bosence 1983).

Within the ecological restraints of light, temperature, substrate, and source, rhodolith distribution is considered most affected by hydraulic energy (Bosence 1983). Periodic rotation appears necessary for rhodolith survival by allowing light to reach all sides and by retarding burial and fouling (Steneck 1986). Excessively strong water motion breaks thalli preventing rhodoliths from forming, while weak currents and wave action cause either stabilization and growth into large algal frameworks or burial by fine sediments leading to death (Adey and MacIntyre 1973, Bosence 1983, Stellar 1993). Bioturbation 
may enhance or replace water motion as a mechanism for rhodolith movement (Minnery 1985, Prager and Ginsburg 1989, Freiwald 1995).

Distribution of shallow rhodolith beds may be controlled by wind driven waves (Bossellini and Ginsburg 1971, Bosence 1976, Stellar and Foster 1995) and tidal currents (Scoffin et al. 1995). Observations of rhodolith beds typically show that reductions or discontinuities in rhodolith coverage coincide with areas of low water motion and sedimentation or areas of high water motion where tidal or wave energy is focused (Bosence 1976, Scoffin et al. 1985, Bosence 1985). For example, in the southwestern Gulf of California, dissipation of wave energy with depth and/or distance from islands and geographic points may limit rhodolith turning enough to restrict bed size and produce bed discontinuities (Stellar 1993). Rapid breakdown of rhodoliths by high water motion above the upper limit of these beds and burial by sediment below the lower bed margin implicate water motion as the most important determinant of bed depth distribution (Stellar and Foster 1995).

Rhodoliths are also found worldwide in deep water on continental shelves and platforms (Logan et al. 1969, Hallock 1988 ,Tsuji 1993, Reid and MacIntyre 1988, Prager and Ginsburg 1989, Minnery 1990, Harris et al. 1996). Even in deep water, currents (Tsuji 1993, Harris et al. 1996) and periodic large storm waves (Prager and Ginsburg 1989) may be sufficiently strong to move rhodoliths.

Movement is also considered to be a critical factor determining rhodolith morphology. Rhodoliths may be branched or have a laminar form. Laminar forms composed of plated crusts surrounding a core of foriegn matter are most common in water depths below $40 \mathrm{~m}$. Rhodoliths with 
branched thalli usually occur in 0 to $30 \mathrm{~m}$ depths (Adey and MacIntyre 1973). For the branched form, branching density is correlated with exposure to wave energy. Deeper rhodoliths tend to have an open, sparsely branched form while shallow ones are densely branched (Figure 1; Bosence 1976, Stellar 1993). Laminar and lumpy branched forms have been reported in shallow areas impacted by high water motion (Bossellini and Ginsburg 1971, Foster et al. , in press). These forms may persist in extremely high energy conditions better than thinly-branched forms because thallus fragmentation is less likely. Variations in rhodolith shape may also be related to movement. Discoidal and irregular forms occur in less exposed areas where infrequent movement leads to flattened growth morphologies, while spherical and ellipsoidal forms are probably a result of more frequent turning in higher energy environments (Figure 1; Bossellini and Ginsburg 1971, Bosence 1983, Minnery 1990, Stellar and Foster 1995).

Although rhodoliths are known to move in the field, few in situ observations of movement or precise measurements of the currents needed for rhodolith transport exist. Observations show a wide range of threshhold velocities. In a wave tank, Bosence (1976) observed movement of individual branched rhodoliths at $8-20 \mathrm{~cm} / \mathrm{sec}$ current velocities. Threshold velocities varied with rhodolith morphology. Scoffin et al. (1985) found that $25 \mathrm{~cm} / \mathrm{sec}$ tidal currents over a ten day period were not strong enough to transport $5 \mathrm{~cm}$ diameter rhodoliths and coralliths. When transplanted into stronger currents on sandy/gravelly substrates, threshhold velocities were approximated as follows: branching rhodoliths, $30-40 \mathrm{~cm} / \mathrm{sec}$; coralliths, $45-65 \mathrm{~cm} / \mathrm{sec}$; "massive" (laminar) rhodoliths, $80-90 \mathrm{~cm} / \mathrm{sec}$. In flume experiments, Harris 
et al. (1996) showed that $2 \mathrm{~cm}$ diameter, laminar rhodoliths from the continental shelf began moving at current speeds of about $45 \mathrm{~cm} / \mathrm{s}$. Initial movement of $5 \mathrm{~cm}$ diameter rhodoliths occurred at $50-60 \mathrm{~cm} / \mathrm{s}$ while $50 \%$ of rhodoliths of this size were moved by $80 \mathrm{~cm} / \mathrm{s}$ currents. Harris et al.'s velocities were referenced to $100 \mathrm{~cm}$ off the substrate. Differences in substrate, current characteristics, and rhodolith morphology may all contribute to these differences in threshold velocities.

In environments where water motion appears too weak to turn rhodoliths, other mechanisms for movement have been suggested. In some communities, frequent repositioning of rhodoliths may occur due to bioturbation by animals such as echinoderms and fish (Minnery 1989, Prager and Ginsburg 1989, Freiwald 1995). Others speculate that weak currents may winnow and undercut supporting sand, causing rhodoliths to frequently rotate in small increments (Bossillini and Ginsburg 1971, Tsuji 1993, Freiwald 1995).

Abundant shallow rhodolith beds along the southwestern shore of the Gulf of California provide an ideal location for examining the hypothesis that the relationship between water motion and rhodolith movement determines rhodolith distribution and morphology. Surveys by Stellar and Foster (1995) and Foster et al. (in press) indicate living rhodolith beds and fossil deposits are widespread in this area. Recent reviews of rhodolith taxonomy in the Gulf show that the dominant species in most beds is Lithophylum margariti (Riosmena-Rodriguez, in prep.). Occasionally, one species in the family Melobesoideae and one in the Maotophoroideae occur (Riosmena-Rodriguez, personal communication). Foster et al. (in press) describe the two types of 
physical environments inhabited by most living beds: 1) gently sloping, subtidal soft bottoms with moderate wave action ("wave beds"; $\quad 2-12 \mathrm{~m}$ deep), 2) relatively level soft bottoms in channels with tidal currents ("current beds"; below $12 \mathrm{~m}$ ). In wave beds, wave action has been observed moving plants. Decreased rhodolith sphericity and branch density with increased water depth indicate deeper rhodoliths are not moved as frequently as shallow plants. Current beds have been assumed to be maintained by tidal flow. Foster et al. (in press) observed that plants with irregular shapes and low branch densities are common in current beds and are similar to those from the lower limits of wave beds (Figure 1). Although morphological differences between and within beds indicate differences in water motion and frequency of movement, these differences have not been quantified. It has also been unclear whether tidal currents move rhodoliths, why rhodoliths in tidal channels are rare above $12 \mathrm{~m}$, or why large discontinuities exist in wave bed distribution.

Most studies examining the relationship between water motion and living rhodoliths have been descriptive or correlative. Although currents in rhodolith beds have been measured and rhodolith movement has been documented over time, rhodoliths have not been observed moving in the field. The lack of strong evidence and presence of conflicting observations requires that further experimentation and observation occur before the hypothesis that water motion controls rhodolith distribution and morphology is widely accepted or used in paleoecological interpretations. The objective of this study is to quantify the relationship between water motion, rhodolith movement, and plant distribution off the southwestern coast of the 
Gulf of California. The specific questions are: 1) What are the water velocities necessary to transport rhodoliths in current and wave beds?, 2) How frequently do rhodoliths move in current and wave driven beds?, 3) What evidence is there for bioturbation?, and 4) How does water motion effect the distribution of rhodolith beds in the Gulf of California? 


\section{METHODS AND MATERIALS}

\section{Study sites}

\section{El Requeson}

Isla el Requeson is located in Bahia Concepcion, a large shallow bay on the Gulf of California side of the Southern Baja Peninsula (Figure 2). The bay is $36 \mathrm{~km}$ long, 3-5 km wide, and oriented in a north/ south direction. Water depths range from $10 \mathrm{~m}$ near the shallow sill at its northern mouth to $40 \mathrm{~m}$ at the southern end. Surface water temperatures in Bahia Concepcion may range from $17-18^{\circ} \mathrm{C}$ in January/February to $30^{\circ} \mathrm{C}$ in September /October (Cardenas et al. 1990, Stellar 1993, Rodriguez-Romero et al. 1994). January and September measurements at El Requeson showed that salinity varied from 35.0 to $36.5 \%$. and secchi disc readings increased from 6.5 to $9 \mathrm{~m}$ (Stellar 1993). Strong winds blow predominantly from N/NW during November to May and blow more variably from the SE the rest of the year (Roden 1964, Candela et al. 1984, Candela et al. 1985, Merrifield et al. 1987).

Numerous living rhodolith beds exist along the western shore of Bahia Concepcion (Stellar and Foster 1995). These beds, up to $1 \mathrm{~km}$ long, grow in water depths of 2-12 m on the wave exposed sides of small islands (such as at Isla el Requeson), geographic points, and open coastline. Wave-washed upper margins grade shoreward into carbonate sand composed of rhodolith and shell fragments, the source material for many small pocket beaches along the coast. At their lower depth limits, beds are bordered by fine sediments. Stellar and Foster (1995) found that most individual plants were fruticose $(89 \%$; for 
form definitions, see Woelkerling et al. 1993) forms while others were foliose (Figure 1). Recent work shows that these are primarily Lithophyllum margariti, a species with highly variable morphology (Riosmena-Rodriguez, in prep.).

The rhodolith bed at Isla el Requeson was selected to examine wave effects on rhodoliths because it is representative of other beds in Bahia Concepcion, and previous work provided valuable background information for this study. The island has a rocky volcanic shoreline with a $>0.5 \mathrm{~km}$ long, subtidal rhodolith bed that wraps around its wave exposed shore (Figure 1). Rhodoliths grow from 4-12 $\mathrm{m}$ deep. The upper edge of the bed is characterized by spherical, densely branched rhodoliths that cover $100 \%$ of the bottom, sometimes up to 2-3 individuals deep. The lower limit consists of less abundant, sparsely branched individuals often covered by fine sediments. Fine sediments continue beyond the lower edge of the bed. Like Stellar (1993), I found that rhodoliths were 1 to $5.6 \mathrm{~cm}$ in diameter, but most were $1-2 \mathrm{~cm}$ for both the upper and lower depths.

\section{Punta Bajo}

An extensive rhodolith bed occurs at $12 \mathrm{~m}$ depth in the channel between Isla Coronado and Punta Bajo just north of Loreto (Figure 2). Foster et al. (in press) described the bed and postulated that it was a tidal current bed in which rhodolith movement occurs primarily due to strong tidal currents flowing between the peninsula and the island. 
Rhodoliths are between $2-6 \mathrm{~cm}$ in diameter and are predominantly foliose, sparsely branched, and irregularly shaped forms of Lithophyllum margariti (Figure 1). At the time of this study, foliose red algae up to $5 \mathrm{~cm}$ long commonly grew attached to rhodoliths throughout the area.

\section{San Lorenzo Channel}

Very large beds of foliose and fruticose forms exist at $12 \mathrm{~m}$ depths in the San Lorenzo Channel (Figure 2). These beds are thought to be maintained by strong currents associated with the tidal flux filling and draining the expansive La Paz Bay (Foster et al. 1996). Tidal current velocities can exceed 60 $\mathrm{cm} / \mathrm{sec}$ at $5 \mathrm{~m}$ depth in the channel (Obeso-Nieblas et al. 1993).

Rhodoliths at this site are 3 to $6 \mathrm{~cm}$ in diameter and are predominantly sparsely branched, irregularly shaped, and foliose forms of Lithophyllum margariti (Figure 1). Extensive mats of Caulerpa sertularoides can cover the rhodolith beds. To eliminate the retardant effects by $C$. sertularoides on rhodolith motion, research was done in an area without the epiphyte.

\section{Methods}

\section{Water Motion}

To quantify the water motion necessary to transport rhodoliths, current measurements with simultaneous video of the beds were made at wave and current beds during periods of high water motion. The current velocity that initiates movement in a rhodolith is the threshhold velocity (Inman 1949, Scoffin et al. 1985, Dyer 1986). Current speed and direction, and water depth were quantified $75 \mathrm{~cm}$ off the substrate with an Inter-Ocean S-4 $\AA^{\circledR}$ current 
meter mounted on a sand anchor. A Sony ${ }^{\circledR}$ TR400 video camera in a Sting Ray $400 \AA$ underwater housing was mounted on another sand anchor about 1 m away. A Pisces $\circledast$ Video Systems Controller, and a SeaBlaze $₫$ halogen light run by two 12 volt batteries connected in series, were programmed to record five minute intervals of real time video every hour for 24 hours or until batteries ran out. Rhodoliths, tagged with neutral buoyancy acrylic yarn, and a flagged stake were set in the camera view for scale. Field of view was approximately $30 \times 30 \mathrm{~cm}$. Currents were sampled within the same 5 minute intervals to identify current velocities that move the rhodoliths. In some cases, 3 minute intervals were used to extend the number of hours documented by the current meter. In wave beds, currents were sampled every 0.5 seconds to identify short period waves (Kinsman 1965). In tidal channels, I assumed short period waves would have little affect on the bottom due to attenuation. Therefore, to maximize number of hours documented, currents were sampled every 1-2 seconds within 5 minute intervals. All equipment was placed using SCUBA and located using bouys, shore line-ups, and GPS.

Morning and afternoon wind velocities were measured daily with a hand held anemometer. Wave period and height were also visually estimated in the morning and afternoon to compare to current meter data.

Video was observed to identify rhodolith movement (including threshhold velocities), the pattern and path of the movement, and the distance transported. Video tapes were also scanned for evidence of bioturbation that might move rhodoliths. 
Current velocities initiating rhodolith movement were identified by observing video and simultaneous current meter data. Mean velocity, velocity frequency, maximum velocity, and standard deviation were calculated using the 150-600 samples collected each 5 minute interval (taken hourly) to examine changes in water movement throughout the day. To determine cumulative direction of flow over time, velocity was separated into geographically meaningful vector components. At the Requeson site, one component represented movement parallel to the shoreline of the island while the other component represented on and offshore movement. At Punta Bajo and San Lorenzo, one component represented flow along the channel and one cross channel flow. A time series of cumulative direction and intensity of water flow was then determined for every record. Spectral analysis of relative water depth from the S-4 pressure transducer at Isla El Requeson was used to identify prominent wave periods and significant wave heights travelling over the rhodolith beds. Spectral analysis was done using MATLAB ${ }^{\circledR}$. Pressure transducer data were also used to determine tidal patterns.

Measurements in wave beds were taken during January and February when N/NW winds are typically the strongest (Merrifield et al. 1987) and resulting waves impacting the beds are the largest. Threshold velocity measurements were taken within the the middle and the upper limit of the wave bed at Isla El Requeson.

Current beds in the San Lorenzo Channel and at Punta Bajo were sampled in January and February during the greatest tidal range of the year (NOAA 1995). Threshold velocities were measured in the middle of the beds 
$(12 \mathrm{~m})$. All measurements were taken at maximum tidal exchange to insure maximum water flow over the beds.

Manipulative experiments were used to examine transport differences between densely and sparsely branched rhodoliths and large versus small sizes in the large wave bed at Isla el Requeson. Branching was considered dense if a plant had an average of 10 or more branches per $\mathrm{cm}^{2}$ and sparse if a plant had less than 5 branches per $\mathrm{cm}^{2}$. Three $2 \mathrm{~cm}$ diameter rhodoliths of both dense and sparse morphology and three $3-4 \mathrm{~cm}$ diameter rhodoliths of dense morphology were interspersed $5 \mathrm{~cm}$ apart between $2 \mathrm{PVC}$ stakes set in the sediment. All nine rhodoliths were tagged with neutral bouyancy yellow yarn in a manner that minimized artificial drag. Three stations were set about $25 \mathrm{~m}$ apart at randomly selected points just below the upper limit of the bed at $4.5 \mathrm{~m}$ and in the middle of the bed at $9 \mathrm{~m}$. Stations were checked immediately after all strong wind and wave events from January 6 to February 5 to see if rhodoliths had moved. Movement was defined as the change of position (in $\mathrm{cm}$ ) of each rhodolith relative to the centerline between PVC stakes. Results of movement events were averaged, and differences in movement between small sparse, small dense, and large dense forms were compared among depths using a Two-factor ANOVA. Location was blocked to remove variation related to location (Winer 1971, Underwood 1981, Zar 1985). All factors were fixed. Alpha level was set at 0.05 . Assumptions of homoscedasticity was tested using Cochran's test. Log and square root transformations were used to correct data for analysis. 


\section{Frequency of rhodolith transport}

Frequency of rhodolith movement was estimated from annual wind and tidal height data, and known transport conditions. At the Requeson wave bed, movement, along with wind and water conditions, was recorded from January 6 - February 5, 1996. This information was used in conjunction with historical wind data collected by Merrifield et al. (1996) to estimate annual frequency of movement. Merrifield et al.'s data, collected at six sites throughout the Northern Gulf of California from November 1983 to March 1985 , is reported as hourly averages and includes wind velocity, direction, and duration. Wind patterns observed among the geographically separate stations are remarkably consistent, indicating wind patterns throughout this area of the Gulf are coherent (Badan-Dagon et al. 1991). Under the assumption that dominant wind patterns observed at Santa Rosalia and Isla Tortuga also occurred at Bahia Concepcion, 85 to $90 \mathrm{~km}$ to the south, the number of days per month that wind events (direction, amplitude, duration) known to move rhodoliths occurred were estimated. Additional historical wind data from the Commision National de Aqua was used to detect patterns and storms affecting shallow rhodolith beds in the Southern Gulf.

Wave forcasting charts from the U.S. Army Corps of Engineers (1984) and linear wave theory were used to make predictions of wave characteristics and bottom particle velocities in wave and current beds.

\section{Bioturbation}

Bioturbation in the rhodolith beds was evaluated with video and SCUBA surveys. Bioturbators and their behaviors were identified. The 
frequency of bioturbation events, defined here as any movement of a rhodolith by an animal, was also determined for the $30 \times 30 \mathrm{~cm}$ field of view of the video camera as the number of events per minute. Preliminary density estimates of large invertebrate bioturbators were made at El Requeson using randomly choosen $1 \times 10 \mathrm{~m}$ swaths, 4 at $4.5 \mathrm{~m}, 4$ at $7.5 \mathrm{~m}$, and 4 at $12 \mathrm{~m}$. Lastly, movement of Toxopneustes roseus through the rhodolith bed at $\mathrm{El}$ Requeson was estimated by tracking individuals over time. Surveyor flags were set next to four individuals at $9 \mathrm{~m}$ where they were most abundant, and the distance moved from the flags was measured after 1,4 , and 10 days.

\section{Regional distribution}

Measured threshhold velocities and estimated frequencies of rhodolith movement were used in conjunction with physical characteristics of subtidal areas to make predictions of rhodolith bed distribution in the southwestern Gulf of California. Coastal morphology, bottom conditions, sedimentation, and wave and current patterns were examined in known beds and bed discontinuities as the basis for predictions of yet undiscovered beds. 


\section{RESULTS}

\section{Water motion}

Fourteen videos of rhodolith beds with simultaneous S-4 records of current speed, current direction, and depth were obtained from January 6 to February 17. Eight of these records were made in the wave bed of Playa el Requeson (101 hours recorded), three in the current bed of Punta Bajo Channel (44 hours recorded), and three in the current bed of San Lorenzo Channel (59 hours recorded). Out of all records, only three from El Requeson documented any rhodolith movement caused by water motion. Bioturbation of rhodoliths was observed numerous times.

\section{El Requeson}

During constant observation of the El Requeson wave bed from January 6 to February 5, three recorded events and two other not documented on video were the only five movement events during the entire period. The undocumented events were identified by mass movement of tagged rhodoliths at $4.5 \mathrm{~m}$ depths and descriptions of strong winds and rough chop by local residents.

The video records show two types of rhodolith motion caused by oscillatory wave currents, rocking and rolling. During high water motion, rhodoliths rocked, sometimes quite steadily and violently, but never actually moved from their position in the bed. Individual or groups of rhodoliths were also observed rolling back and forth along the bed in the direction of 
wave propagation. In video records, individual plants rocked up to 15 times a minute and one plant rolled as far as $95 \mathrm{~cm}$ from its original position.

Water velocities initiating rolling and rocking were very similar in all three records. On January 23 at $5 \mathrm{~m}$ depths, rhodoliths were observed moving due to wind propagated swells from the NW. Waves caused oscillating bottom currents trending NW/SE with maximum velocities of $38 \mathrm{~cm} / \mathrm{s}$ and frequent velocities over $20 \mathrm{~cm} / \mathrm{s}$ (Table 1, Figure $3 \& 4$ ). Plants began to rock at 20 to $25 \mathrm{~cm} / \mathrm{s}$ velocities. Oscillatory currents of $25-30 \mathrm{~cm} / \mathrm{s}$ initiated rolling of small $(<2 \mathrm{~cm}$ diameter) plants with sparse to medium branch density or plants that were in unstable positions on the substrate. At $30-35 \mathrm{~cm} / \mathrm{sec}$, more extensive rolling was observed. At these velocities, plants over $3 \mathrm{~cm}$ in diameter with dense branches were observed rolling. Up to $25 \%$ of surface rhodoliths were observed moving at once. After rolling had occurred, stronger velocities were often required to initiate rocking or rolling again (Table 1). Observations of the manipulation experiment the following day showed that all tagged rhodoliths at $4.5 \mathrm{~m}$ depth and up to $100 \mathrm{~m}$ apart had shifted from their original positions, indicating widespread rolling and movement within the bed.

On February 3 and 4, NW winds caused swells to build and peak in the afternoon. Waves caused oscillating bottom currents trending NW/SE with maximum velocities of 27.2 and $45 \mathrm{~cm} / \mathrm{s}$ respectively (Figure $4 \& 5$ ). During the February 3 event, no rolling occurred on video, but much strong rocking was observed at 20 to $25 \mathrm{~cm} / \mathrm{s}$ current velocities (Table 1). By the next morning, no tagged rhodoliths had moved in the manipulation experiment. During the afternoon of February 4, rhodoliths at $4.5 \mathrm{~m}$ depths were rocking 
at $15-25 \mathrm{~cm} / \mathrm{s}$ and beginning to roll at $25-35 \mathrm{~cm} / \mathrm{s}$ (Table 1, Figure 5).

Widespread movement of tagged rhodoliths at $4.5 \mathrm{~m}$ depth experimental sites occurred during this time.

No other movement was observed on video from January 6 to February 5. However, displacement of tagged rhodoliths after high wave conditions indicate two other events occurred during this time. Maximum current speeds ranged from 11.8 to $20 \mathrm{~cm} / \mathrm{s}$ during the five days beds were video taped, but no movement was observed.

In all but one record, the progressive vector plot indicates a cumulative long shore flow of water along the exposed side of Isla el Requeson. During periods of strong NW winds, oscillatory wave motion occurred perpendicular to shore, but the cumulative water motion past the current meter was alongshore towards $160^{\circ} \mathrm{SE}$ (Figure 6). On days when winds were not as strong, current velocities were weaker and the patterns were not as clear.

Field observation and spectral analysis indicate a clear pattern of wind generated waves in Bahia Concepcion. Typically N to NW winds begin in the late morning creating small waves. Over time, wind blowing across the 30 $\mathrm{km}$ of open water causes waves to build until they may reach maximum heights of $1 \mathrm{~m}$, periods of 3-4 s, and significant wave heights of $0.6 \mathrm{~m}$ (Figure $7 \& 8$ ). Rhodoliths were observed moving during these conditions. The evening drop in wind brings a resulting drop in wave produced bottom currents (Figure $3 \& 5$ ). Hand held anemometer records and visual estimates of wave data confirmed the results of the spectral analysis.

At El Requeson, maximum tidal lows most often occurred in the afternoon (Figure $3 \& 5$ ), coinciding with maximum wave energy and bottom 
current velocities. The maximum tidal range observed was $1.0 \mathrm{~m}$. Ranges measured during the afternoons when rhodoliths were observed moving were $0.85-0.65 \mathrm{~m}$.

In the tagged rhodolith experiment, rhodoliths moved from their initial positions only three times between January 6 to February 5. The largest movement of a rhodolith from its starting position was $95 \mathrm{~cm}$. No statistically significant difference in movement from starting position between dense and sparsely branched or between small and large rhodoliths. Movement was highly variable. There was a significant difference between movement at 4.5 and $9 \mathrm{~m}$ depths (Table 2). While most tagged rhodoliths moved at $4.5 \mathrm{~m}$, almost none moved at $9 \mathrm{~m}$ (Figure 9). Over time, tagged rhodoliths at $9 \mathrm{~m}$ became covered in fine sediment and, in some cases, diatom mats. Rhodoliths set at $40 \mathrm{ft}$ on January 11 th had moved little when checked on February 5 th. Those that had moved were probably moved by sea cucumbers or foraging fish.

\section{Punta Bajo}

Three videos with simultaneous current meter records totaling 44 hours were made from January $18-20$. Between January 18 and 19 the current maximum was $23.9 \mathrm{~cm} / \mathrm{s}$. The video failed, but three $4 \mathrm{~cm}$ diameter tagged rhodoliths set on the substrate moved up to $25 \mathrm{~cm}$ during this time. In the other two records, tagged rhodoliths were nestled in with other rhodoliths. Currents up to $36.9 \mathrm{~cm} / \mathrm{s}$ were recorded, but tagged rhodoliths did not change position, and no rhodolith movement occurred in videos (Table 1, Figure 10). 
Velocity vector analysis shows that cumulative water flow was unidirectional through the channel ( $30^{\circ} \mathrm{NE}$-True North), changing direction with the tides (Figure 11).

On the afternoon of January 20th, strong NW winds generated swells up to $1.5 \mathrm{~m}$ high. Currents up to $36.9 \mathrm{~cm} / \mathrm{s}$ were recorded during this time (Figure 10). Because the tidal ebb was close to completion during this time, maximum velocities were probably due to waves. The maximum $1.3 \mathrm{~m}$ tidal range measured occurred during these three days.

\section{San Lorenzo Channel}

No rhodoliths moved during the two 24 hour and one 11 hour periods recorded with video and current meter (Table 1). Maximum current velocity recorded was $36.8 \mathrm{~cm} / \mathrm{s}$ (Figure 12). The maximum tidal range recorded was $1.7 \mathrm{~m}$.

Like Punta Bajo, velocity vector analysis showed that cumulative water flow was unidirectional through the channel, changing direction with the tides ( $120^{\circ} \mathrm{SE}-300^{\circ} \mathrm{NW}$; Figure 11).

\section{Frequency of rhodolith movement}

Field observations and analysis of historical wind data indicate rhodoliths in the shallow part of wave beds $(4-5 \mathrm{~m})$ may move frequently during winter months. Observations showed that winds blowing consistently from the N/NW with velocities greater than $6 \mathrm{~m} / \mathrm{s}$ for longer than 4 hours were necessary to create the wave conditions that transported rhodoliths ( $1 \mathrm{~m}$ 
maximum wave height, 0.6 significant wave height, 3-4 second period). From January 6th to February 5th, 1996, these wind characteristics occurred during five separate days. Rhodolith movement was observed on video during three of these days. Widespread displacement of tagged plants was observed after the other two events. Analysis of 17 months of wind data from Santa Rosalia and Isla Tortuga indicates that wind conditions may be suitable for rhodolith transport in the shallow end of wave beds 87 days a year. These records suggest most rhodolith movement occurs in the winter months when as many as 18 days a month may be windy enough for transport. Predominantly Southerly winds with reduced velocities in the summer indicate rhodoliths may not move much in these months (Table 3, Figure 13).

\section{Bioturbation}

The most common bioturbators identified at El Requeson were fish and large invertebrates. Spotted sandbass (Paralbrax maculofasciatus), Pacific porgy (Calamus brachysomus), and bullseye puffers (Sphoeroides annulatus) were all observed picking at and lifting rhodoliths as they foraged for invertebrates living in thalli interstices. The round stingray (Urolophus halleri) and bullseye stingray ( $U$. concentricus) were observed swimming through the beds. A stone scorpionfish (Scorpaena mystes) was observed making a burrow at the outer edge of the bed. Numerous ray pits and mounds of unidentified origin were evident throughout the bed.

The rose urchin (Toxopnuestes roseas), Murex snails (Murex sp.), and sea cucumbers (Isostichopus fuscus) occurred throughout the bed in low 
densities (0-1 individual per $\left.10 \mathrm{~m}^{2}\right)$. Visual surveys indicated $T$. roseus and $I$. fuscus were most abundant from 7.5-12 $\mathrm{m}$ depths. Deposit feeding I. fuscus commonly lay at the end of meter long tracks through the sediment surface. Piles of feacal pellets containing fine sediments and rhodolith fragments were often evident at their posterior.

Tagged $T$. roseus moved through rhodolith beds. Velocity of tagged $T$. roseus was $0-25 \mathrm{~cm}$ in one day and $5-42 \mathrm{~cm}$ in 10 days. Tagged animals moved an average of $20 \mathrm{~cm} / 10$ days \pm S.D. 16.5. Urchins had up to $100 \%$ cover of rhodoliths and shell fragments on their tests. Over the period observed, some burrowed into the bed until their tops were flush with the surface.

In the San Lorenzo bed, Sphoeroides annulatus, Urolophus halleri, and $U$. concentricus frequently occurred on video tapes. Myrichthys maculosus and small $(4-6 \mathrm{~cm})$ unidentified crabs were observed burrowing under and disturbing rhodoliths. Numerous sea stars (Pentaceraster cumingi), up to 5 individuals per $1 \mathrm{~m}^{2}$ in some areas, occurred throughout the bed.

No bioturbators were observed in the Punta Bajo bed. In all three sites, however, the video recorded rhodoliths being pushed up by movement of animals beneath the bed surface. In most cases, after a $9-25 \mathrm{~cm}^{2}$ portion of bed was lifted up, rhodoliths settled back into their previous positions. In the San Lorenzo bed, crabs and M. maculosus caused this type of rhodolith movement. It is unclear whether they were responsible for similar rhodolith movement at El Requeson and Punta Bajo. 
The number of bioturbation events during 11 5-minute videos of the Punta Bajo bed varied from 0-5/5 minutes with an average of 1 event/ 5 minutes \pm SD 1.4. All events were slight lifts of a $9-25 \mathrm{~cm}^{2}$ portion of the bed from animal activity underneath. All lifting events resulted in rhodoliths settling back into their previous positions. Out of 585 -minute intervals recorded in the Requeson bed, an average of 1 event/ 5 minutes \pm SD 1.26 with a maximum number of 6 events $/ 5$ minutes occurred. Fish and hermit crabs were responsible for some bioturbation, but most observed events were lifts of the bed from unidentified animals below. The majority of lifts resulted in rhodoliths settling back into their previous positions. Bioturbation was most frequent in the videos of the San Lorenzo bed. Out of 645 -minute intervals observed, an average of 5 events / 5 minute \pm SD 3.5 with a maximum number of 15 events $/ 5$ minute occurred there. Myrichthys maculosus and crabs were observed burrowing under and disturbing rhodoliths. Slight lifts of the bed occurred most of the time. More activity occurred during the night. 


\section{DISCUSSION}

\section{Factors affecting rhodolith transport}

Numerous factors affect the threshold velocity of a rhodolith, including individual characteristics, contact with the substrate, current characteristics, and fouling (Figure 14). Particle transport theory predicts individual rhodolith morphology is an important factor determining threshold velocities (Dyer 1986, Denny 1988). Individual variation in size, shape, surface area to volume ratio, and density (weight/volume) contribute to a rhodolith's response to water flow. Observations indicate that rhodoliths with lower surface area/volume and higher weight/volume need greater current velocities to initiate movement (Bosence 1976, Scoffin 1985, Personal obs.). Lumpy or laminar rhodoliths (low surface area/volume, high weight/volume) require higher velocities for entrainment than branched thalli (high surface area/volume, low weight/volume) of the same size. Also, irregular and discoidal forms are more stable than spheroidal or ellipsoidal forms (Bosence 1976, Personal obs.).

Threshold velocities are also dependent on the relationship between rhodolith and substratum. Studies on sediment transport show that it is harder for fluid flow to move a grain out of a densely packed surface layer than out of a loose one (Dyer 1986). Rhodoliths partially buried in sediment or on substrates with high relief will probably need more energy to move than those on a flat surface. In the field, rhodoliths are often dense enough to form an algal framework in which individual thalli are in contact with or buried by other plants (Bosence 1976, Scoffin et al. 1985, Littler et al. 1991, 
Stellar 1993). Branched thalli may even interlock (Scoffin et al. 1985). Contact with other rhodoliths in an algal framework creates resistance to entrainment and causes higher threshold velocities. Indeed, tagged rhodoliths set on top of the Punta Bajo bed moved $25 \mathrm{~cm}$ in currents that did not exceeded $24 \mathrm{~cm} / \mathrm{s}$ velocities, while the same rhodoliths placed in the bed framework did not move in currents reaching $37 \mathrm{~cm} / \mathrm{s}$ velocities. The density of rhodoliths in an area and extent that branches interlock will determine the effect the algal framework has on rhodolith movement.

Epifauna and epiflora growing over rhodoliths may have a large effect on their movement. Epiphytes change the form of particles causing different responses to water flow. For example, the $2-5 \mathrm{~cm}$ foliose algae growing on rhodoliths at Punta Bajo undoubtably provide more resistance to currents than the low profile rhodolith framework. The increased drag may cause rhodoliths to move easier than if they had no epiphytes. Conversely, the sponges (Lucetta losangelensis, Tendania sp., Mycale sp.), tunicates (Polyclinum laxum, Aplidium sp.), and anenomes (Diadumene lineata, Haplanella luciae) growing on rhodoliths at El Requeson often bind groups of rhodoliths together. These large conglomerates will resist entrainment. Mats of the green alga Caulerpa sertularoides growing over the San Lorenzo bed are porous and allow water to flow through, but clearly inhibit rhodolith motion.

Differences in threshold velocities are partially due to differences in water motion. The acceleration of water in oscillatory waves exerts more total force on an object than constant flow of the same velocity (Denny 1988). Therefore, wave induced currents should transport rhodoliths at lower 
velocities than tidal currents. This may be the reason rhodoliths in Punta Bajo and San Lorenzo beds were not moved by $37 \mathrm{~cm} / \mathrm{s}$ tidal currents, although $25-35 \mathrm{~cm} / \mathrm{s}$ wave induced currents transported rhodoliths at $\mathrm{EI}$ Requeson. Also, the foliose, sparsely branched, and irregularly shaped rhodoliths that predominate in the Punta Bajo and San Lorenzo beds may represent more stable morphologies than the fruticose, densely branched, spherical, and smaller forms that predominate at El Requeson.

\section{Comparison of rhodolith threshold velocities}

Although numerous studies have investigated the threshhold of particle motion under unidirectional currents (Hjulstrom 1939, Sheilds 1936, Inman 1949, Sundborg 1956, Miller and Komar 1977 ) and oscillatory water waves (Komar and Miller 1973), the empirical models resulting from this work are based primarily on flume experiments and field observations of sand sized quartz grains. Therefore, they have limited predictive use for a range of grain size, densities and flow conditions (Miller and Komar 1977) such as in rhodolith beds.

Several studies have specifically examined threshhold velocities for rhodoliths. However, variation in rhodolith morphology, substrate, current characteristics, and methods among studies limits the comparison of results (Table 4). For example, the threshold velocities recorded in the laboratory by Harris et al. (1996) are probably higher than those recorded by Bosence (1976) for several reasons: Bosence tested individual rhodoliths set on a single layer of medium grained sand stuck to a metal plate while Harris et al. tested 
evenly spaced groups of rhodoliths on a bed of sand; the flow used in Harris et al.'s study was unidirectional as opposed to the oscillatory wave motion used by Bosence; lastly, Bosence tested branched rhodoliths while Harris et al. used laminar forms which have higher weight/volume and lower surface area/volume ratios. The only known observations of threshold velocities in unmanipulated rhodolith beds for both unidirectional and oscillatory water flow are those made in this study. These field measurements include the effect of the densely packed algal framework and natural irregularities in the substrate, factors not examined in other studies.

Comparisons between studies are ultimately confounded because velocity measurements recorded are relative; they are not the absolute velocity values that impact the top of beds. Studies on rhodolith movement have recorded current velocities at different heights above the substrate $(5 \mathrm{~cm}$, Scoffin et al. 1985; $100 \mathrm{~cm}$, Harris et al. 1996; $75 \mathrm{~cm}$, this study) or calculated them using linear wave theory (Bosence 1976). These observations, made at a distance from the bed surface, do not account for friction and water viscosity which slow water as it moves over the seabed, causing velocities to exponentially increase away from the bed. This velocity gradient, known as the benthic boundary layer, changes depending on current characteristics, bed roughness, and water viscosity (Dyer 1986, Denny 1988). The benthic boundary layer may be thick in unidirectional currents, affecting velocities throughout the water column. In waves, the benthic boundary layer is typicaliy very thin no matter what the bed roughness (Dyer 1986, Denny 1988). For a wave with a four second period, the benthic boundary layer may be 0.7 $\mathrm{cm}$ to a few $\mathrm{cm}$ thick (Dyer 1986). 
Because studies on rhodolith movement have recorded current velocities at different heights above the substrate and in varying conditions, some correction is necessary to offset effects of the benthic boundary layer to compare results. Ideally, multiple current meters at different heights above the bed should be used to produce a velocity profile from which near bed current velocities can be extrapolated. Alternatively, a rough conversion of current velocities to different heights above the substrate can be made for unidirectional flow (Harris et al. 1996; Appendix 1).

After converting unidirectional current data to $5 \mathrm{~cm}$ over the bed, the maximum velocity of tidal currents in the San Lorenzo Channel is 20-25 $\mathrm{cm} / \mathrm{s}$. Due to the thinness of the benthic boundary layer in oscillatory flow, we can assume threshold velocities measured off the substrate at El Requeson wave beds are close approximations to near bed velocities. Under these assumptions, the maximum tidal flows over rhodoliths in the San Lorenzo Channel are less than the oscillatory current velocities $(25-35 \mathrm{~cm} / \mathrm{s})$ needed to move rhodoliths in wave beds (Table 4). Scoffin et al. (1985) showed that individual branched rhodoliths moved in $30-40 \mathrm{~cm} / \mathrm{s}$ tidal currents. The dense algal framework and irregularly shaped, sparsely branched rhodolith forms found at Punta Bajo and the San Lorenzo Beds are conditions that may require even greater threshold velocities. It is unlikely that tidal currents move rhodoliths in the deep channel beds.

\section{Relationship between transport and rhodolith morphology}

Tagging experiments at 4.5 and $5 \mathrm{~m}$ depths in the El Requeson wave bed showed high variability and no apparent difference in movement 
between small versus large and sparsely versus densely branched forms. However, differences may have been obscured because the net result of oscillatory motion was examined. A rhodolith may have moved a great cumulative distance but deposited near its initial position. Form undoubtedly affects transport, however position within the framework, substrate, and micro-topographical difference may have a greater effect in densely packed beds like El Requeson.

While rhodolith morphology may affect transport, movement is considered to be a critical factor determining rhodolith morphology. As discussed earlier, studies in nearshore areas worldwide have indicated that the distribution of shape, size, and branching density correlates with hydraulic energy (Bossellini and Ginsburg 1971, Bosence 1983, Minnery 1990, Foster et al., in press). Results of this study confirm a correlation between morphological variation and frequency of transport. Spherical, densely branched plants are more abundant in the shallow margins of wave beds where transport by water motion may be frequent in the winter months. Irregularly shaped rhodoliths with low branch densities are more abundant in the deeper areas of wave beds and in the deep current beds where transport by water motion only occurs episodically due to large storms.

The affect of transport on rhodolith morphology is unclear. At El Requeson, vigorous rocking (up to 15 times/minute) punctuated by occasional rolling or saltation across the bottom could have an enormous impact on apical growth on the thalli. Bosence (1983) suggested that dense branching occurs because apical abrasion incurred during turning stimulates intercalary branching or lateral filament growth below the apex. Foster et al. 
(in press), however, found that apical branching can be more common in shallow (versus deep) water. In either case, whether growth is triggered by movement, light, sedimentation, or an interaction of these factors is unknown, but more movement in shallow areas could be the cause of predominantly higher branch densities in these areas.

Because rhodolith form, bed framework, and currents may vary within a small area of a bed, with depth in a bed, or between beds, rhodolith movement may differ accordingly. Observations of videos of El Requeson bed at $4.5 \mathrm{~m}$ show that rhodoliths, even within a small area, move at different current velocities. On a larger scale, rhodolith morphology often differs with depth within a bed (Bosence 1976, Stellar and Foster 1995) and differs between current and wave beds (Foster et al., in press). Therefore, average threshhold velocities are expected to differ. Spherical, densely branched plants that live in upper sections of El Requeson wave beds probably move at lower velocities than sparsely branched, irregular shaped plants found deep in wave beds and in current beds. Because rhodoliths in the deeper sections of wave beds and in the current beds may have higher threshhold velocities and because strong water motion may not be as common at these depths, less frequent movement may result. Rhodoliths in current beds may have the highest threshold velocities because water flow is more laminar and constant and the plants are sparsely branched.

Observations at El Requeson showed that equally high velocities do not always initiate entrainment of the same rhodoliths (Table 1). During a period of high water motion, the framework may become increasingly stable. Velocities sufficient to transport rhodoliths early in a time series did not 
initiate entrainment later on. Bioturbation could destabilize the framework during periods of low water motion. In addition, velocity may not be the best flow characteristic to describe rhodolith motion. Video and current records taken over a sandy bed by Davies (1980) showed that although some of the largest current velocities caused movement of sand grains, many instances of movement occurred with smaller velocities. He found that velocity measurements by current meters over-simplified the complex laminar and /or turbulent flow patterns interacting with the uneven surfaces of the sea floor to ultimately initiate sediment transport.

\section{Predicted mechanisms and frequency of rhodolith movement}

The typical winter wind pattern at $\mathrm{El}$ Requeson is for N/NW breezes to develop in the late morning. As the day goes on, wind speed increases and waves of increasing height and period arrive at the exposed side of the island until waves with a maximum period of 3-4 seconds, maximum height of $1 \mathrm{~m}$, and significant height of $0.6 \mathrm{~m}$ form. These are the conditions in which rhodoliths in the shallow part of the bed moved. Visual observations in January 1991 (Stellar 1993), and March 1996 (Foster, personal communication) support the observations made between January 6 and February 5, 1996.

When high wave action is coupled with low tides, as observed in January 1996, the wave energy impacting the bed increases. After the January 1991 and 1996 events, rhodoliths at the deep end of the bed at 9 and $12 \mathrm{~m}$ did not move but were covered by fine sediments. Wave prediction tables from the U.S. Army Corps of Engineers (1984) indicate that under the observed wind speeds and wind direction, the 15 to $25 \mathrm{~km}$ fetch (from Northern Bahia Concepcion 
to El Requeson) limits waves to the observed significant heights and periods . If wind speeds are greater, larger waves will be generated. However, if winds rarely rise above the maximum observed $(11 \mathrm{~m} / \mathrm{s})$, the fetch across Bahia Concepcion limits the wave energy arriving at El Requeson and, therefore, limits the depth of wave induced rhodolith movement. Abundant fine sediments at the deep margins of the bed are strong evidence that wave energy is limited. Rhodoliths at the deep margins of beds may only move occasionally during large storms or due to bioturbation.

Observed cumulative longshore current during moderate to high wave energy at El Requeson indicates cumulative rhodolith transport is in a SE direction along the island. Over a three day period with strong NW winds and $1 \mathrm{~m}$ seas, Stellar and Foster (1995) observed that a pile of rhodoliths placed at the upper margin of the bed gradually moved until rhodoliths formed a 1-3 $\mathrm{m}$ long band perpendicular to the swell direction. Over time, longshore transport of shallow rhodoliths could have considerable impact on rhodolith production and deposition.

It is unclear whether the SE winds that occur during the summer/fall and occasionally during the rest of the year create large enough swell to move rhodoliths. If they do, beds in areas protected by the usual swell pattern may be disrupted and reversals of longshore sediment transport may occur. Wave prediction tables (U.S. Army Corps of Engineers 1984) show that if $10-11 \mathrm{~m} / \mathrm{s}$ winds blow for over 2.5 hours from the SE, a $16 \mathrm{~km}$ fetch (the maximum stretch of open water from the south end of Bahia Concepcion to $\mathrm{El}$ Requeson) is enough distance for $0.6 \mathrm{~m}$ significant height, $3.5 \mathrm{~s}$ waves to form. Under these conditions, some rhodolith movement would occur. However, 
wind records show that summer SE winds are rarely this strong for extended durations (Figure 13). Movement due to SE winds is probably uncommon.

It is clear that in the shallow areas of wave beds like El Requeson, rhodoliths move frequently during the winter. The February 1996 observations that conditions were suitable to move rhodoliths 5 times a month may be an unusually low frequency for a winter month. Wind records from Isla Tortuga and Santa Rosalia (85-90 km North of El Requeson) indicate that wind conditions necessary to move rhodoliths in the shallow parts of wave beds may occur 14 - 18 days a month from November to December (Table 3). Local residents of Bahia Concepcion often commented that the winter of 1996 was "mild" and "less windy than usual". No quantitative evidence is available to substantiate this condition, but a low wind year would explain the discrepency between my observations and Merrifield et al's (1987) long term records. Large storms and bioturbation may be the only mechanisms for movement at deeper edges.

Shallow "wave" beds do occur throughout the western Gulf of California (Foster et al., in press; Riosmena, personal communication). Wind records from La Paz (Commission National de Agua, unpublished) indicate annual wind patterns in the lower Gulf are similar to the patterns documented by Merrifield et al. (1987). If this is so, similar processes and frequency of movement occur in beds gulf wide. If beds are not fetch limited, the duration of strong winds determine wave height and period (U.S. Army Corps of Engineers 1984 ). In beds with unlimited fetch, increased wave energy and resultant increase in bed transport may occur to greater depths than at El Requeson. In such beds, low amounts of fine sediments and 
possibly more spherical, densely branched plants would occur deeper. Upper limits may also occur deeper as higher wave energy could inhibit shallow rhodolith formation.

In deep rhodolith beds $(12 \mathrm{~m})$, tidal currents do not appear sufficient to move rhodoliths. Occasional movement from bioturbation or severe storms may be the only process of transport in these areas. Linear wave theory calculations indicate that at least $2 \mathrm{~m}$ high swell with a 6-7 second period must occur for oscillatory current speeds at $12 \mathrm{~m}$ depths to reach $30-35 \mathrm{~cm} / \mathrm{s}$ (suitable for rhodolith transport in wave beds). Winds blowing consistently at $10 \mathrm{~m} / \mathrm{s}$ for 10 hours with over $100 \mathrm{~km}$ of fetch will cause such waves to form (U. S. Army Corps of Engineers 1984) (Table 5; Appendix 2). In the middle of the Gulf at Isla Tortuga, winds of these strength and duration are typical in the winter, however, measurements taken at $\mathrm{La} \mathrm{Paz}$ and Santa Rosalia indicate dominant wind speeds are much lower near the coast (Commission National de Agua, unpublished; Merrifield et al. 1987) Therefore, deep beds like San Lorenzo and Punta Bajo, located close to the coastline in channels with restricted fetch, probably only move from water motion during the hurricanes and other large storms that occasionally move through the Gulf (Roden 1964).

The fact that epiphytes have been able to develop on rhodolith thalli throughout many areas is a strong indication that motion is infrequent in these areas. The mats of the green algae Caulerpa sertularoides growing over the San Lorenzo bed and the foliose red algae prevalent on the top of plants at Punta Bajo would not develop if the beds were frequently disturbed. Stellar (1993) observed that sponge, tunicate, and anenome mats were usually most 
abundant in the middle of the El Requeson bed at 8-9 $\mathrm{m}$ where water motion, even in the winter, is not usually strong enough to transport rhodoliths. However, she did observe that overall abundances of these animals decreased from January to October. Foster et al. (1996) have observed beds in Bahia Concepcion covered with blue green alga/diatom mats in the fall and thick growths of the brown algae Hydroclathrus clathratus occuring in summer and early fall. They have also observed large areas of beds near Isla San Jose overgrown by $C$. sertularoides during late summer, early fall. Seasonal and annual fluctuations of epiphytes in conjunction with seasonal differences in water motion may play an important role in stabilizing rhodolith beds.

SCUBA and video observations made in this study indicate that bioturbation may be an important cause of rhodolith movement throughout the rhodolith beds of the Gulf of California. Many species including rays, fish, eel, sea cucumbers, urchins, sea stars, crabs, and molluscs appear to actively disturb rhodolith beds. Numerous pits and mounds found throughout beds are further indication that bioturbation is common (Foster et al. 1996, personal observation.). A $30 \times 30 \mathrm{~cm}^{2}$ area had up to 15 bioturbation events in a 5 minute period. Most of these events were slight lifts of the bed due to unidentified burrowing animals. Although rhodoliths are not overturned in these events, the frequent shifting of bed framework may keep thalli from prolonged contact with the substrate or other rhodoliths and may act to prohibit fouling by fine sediments. The rates of bioturbation that actually turned rhodoliths over in the $30 \times 30 \mathrm{~cm}^{2}$ video frame ranged from 0 to $36 \mathrm{~cm}^{2} / 5 \mathrm{~min}$. Differences in bioturbator densities within and among beds could have an important influence on rhodolith bed ecology. In deep 
tidal channels like San Lorenzo and Punta Bajo and in the deep portions of wave beds like El Requeson where water motion is rarely strong enough to transport rhodoliths, bioturbation may be the primary source of movement.

Many studies have examined the rates at which organisms rework sediments through activities such as burrowing and feeding (see review by Carney 1981). Two intertidal mudflat studies estimate that rays, which hydraulically excavate pits to obtain benthic prey, can turnover an $800 \mathrm{~m}^{2}$ area in 70 days (Trush et al. 1991) and a $10 \mathrm{~km}^{2}$ area in 72 days (Myrick and Flessa 1996). More widespread sampling of bioturbation activity coupled with good estimates of bioturbator densities would give a better idea of the role of bioturbation in rhodolith beds.

Alternative mechanisms that allow rhodoliths to survive without movement may exist. Littler et al. (1991) concluded that rhodoliths living from 67 to below 200 meters on the San Salvador Seamount, Bahamas remain stationary but may translocate metabolites to lower surfaces or have some heterotrophic utilization of a dissolved energy source and thus grow spherically. Scoffin et al. (1985) reported spherical rhodoliths living in "subthreshhold water velocities" in Muri Lagoon, Cook Islands. They concluded that rhodolith surfaces can continue to live underneath the sandy substratum for up to several months between periods of high water motion. Water flushing through the sand and gravel may move grains so that no part of a rhodolith is in direct contact with sediments for a fatal length of time. Extensive sand ripples in the $12 \mathrm{~m}$ beds near Isla San Jose are evidence that sediment is transported in some beds. (Stellar, personal communication). Many crustose corallines have low light requirements for growth 
(Adey and Vasser 1975, Littler et al. 1985, Luning 1990). It is possible that light filtering and refracting through the rhodolith bed framework is sufficient to allow growth on the lower surfaces of thalli. Crustose corallines can also remain alive during extended periods of darkness (Miles and Meslow 1990, Kendrick 1991, Luekart 1994). In the Gulf, rhodolith surfaces that are covered, even buried, appear healthy and could potentially stay that way for long periods (personal observation; James,personal communication). Coralline crusts are commonly very slow growing algae accreting at rates of 0.2 to 27.6 mm/year (Bosence 1983, Edyvean and Ford 1987, Matsuda 1989, Luekart 1994). Slow growth and infrequent repositioning may be sufficient for growth in all directions to produce the spherical rhodolith form (Prager and Ginsburg 1989). Translocation and/or the ability to persist in darkness for long periods may aid stationary, spherical growth.

Factors controlling the regional distribution of rhodoliths in the SW Gulf of California

The regional distribution of rhodolith beds in the SW Gulf of California does not appear to be as dependent on water motion as was previously thought (Foster et al., in press). Disturbance by animals coupled with infrequent transport during storms appear to be suitable conditions for rhodolith bed maintenence in deep "channel" beds, such as at Punta Bajo and San Lorenzo, and in the deeper margins of wave beds like those in Bahia Concepcion. However, water motion, even at sub-threshold velocities, may be important to plants because it supplies nutrients and deters fouling by fine 
sediments. Water motion can deter the establishment of a rhodolith bed if thalli are regularly broken by high velocities (Stellar and Foster 1995).

If rhodolith beds are not dependent on frequent flows at thresholdlevel velocities, the primary controlling factors for regional distribution may be light, bottom conditions, sedimentation, and source material. Secchi depth measurements taken in the Gulf (Stellar 1993, Lechuga-Deveze 1994, FloresRamirez 1994) indicate that the euphotic zone depth (1\% surface illumination) is $18-30 \mathrm{~m}$ in the Gulf (Holmes, 1970). Therefore, only beds at $30 \mathrm{~m}$ or deeper are potentially light limited. Because corallines are typically found growing in sub-optimal light conditions, lower limits of growth may be quite deeper (Littler et al. 1985, Luning 1990). Deep beds have been found west of Isla San Jose ( $30 \mathrm{~m}$ depth; Foster et al., in press) and south of $\mathrm{LaPaz}$ ( to $80 \mathrm{~m}$ depth; Dawson 1960 , Riosmena-Rodriguez, personal communication). Dredging may show many more deep beds in the Gulf.

Temperature and light may limit rhodoliths in shallow water. Rhodoliths have been observed to become bleached and brittle when water reaches temperatures near $30^{\circ} \mathrm{C}$ in shallow lagoons (Stellar 1993).

Most rhodolith beds have been found on gently sloping or level sandy bottoms (Bosence 1983; Foster et al., in press). Steep bottoms may reduce the chances for rhodoliths to remain and develop in one area, and rocky bottoms may increase thalli breakage. Some uncommon resistant, lumpy forms have been found in shallow cobble areas with high wave exposure (Foster et al., in press), and a bed has recently been found at $50 \mathrm{~m}$ on a rocky platform off Ensenada de Muertos south of La Paz (Riosmena-Rodriguez, personal 
communication). Resistant forms may be the only ones able to persist on rocky bottoms in areas of high water energy.

Sedimention coupled with low water motion may be an important limiting factor for rhodolith beds in the Gulf. High amounts of fine sediments are unusual in rhodolith beds except at the deep margins (12 $\mathrm{m}$ ) of wave beds such as at El Requeson where rhodoliths have sparse, elongated branches and plant density is low. Photosynthesis does not appear to be limited at these depths. Perhaps rhodolith growth is inhibited at these deep margins by fouling or burial due to high rates of fine sedimentation and/or lack of water motion to remove the fine particles. Rhodolith beds are absent from areas near mangroves, sites of high sedimentation especially of fine organics. They are also absent at the mouths of arroyos, sites of infrequent but prolific sedimentation, and along the entire east side of Bahia Concepcion, a mountainous peninsula with high erosion rates and coastline protected from most wind generated wave action (Mendahl, personal communication). Cores taken off the mouths of arroyos flowing into Bahia Concepcion just south of El Requeson do show lenses of rhodolith fragments (Barns, personal communication). These indicate occasional storm transport of nearby rhodoliths to the area or burial of incipient in situ beds by arroyo-transported sediments. In both the Florida Keys (Bosence 1985) and Mannin Bay, Eire (Bosence 1976), rhodoliths were stabilized or buried and often reduced in density in areas of low water motion with high amounts of fine sediments. High sedimentation, especially of fines, may also impact invertebrate behavior or distribution, reducing bioturbation rates in a bed. 
Rhodolith bed distribution is also influenced by source material. In the rhodolith beds investigated so far, most rhodolith reproduction appears to occur from fragmentation. Few rhodoliths with viable conceptacles have been found (Riosmena-Rodriguez, personal communication). If fragmentation is the primary reproductive mode, some suitable source must be available for a bed to form. The proximity of other beds or nearshore rocks encrusted with rhodolith forming corallines would determine the potential for rhodolith bed formation.

Although knowledge of their effects on rhodolith bed distribution is incomplete, the influence of water motion, light, bottom conditions, sedimentation, source material, and bioturbation should be considered in attempts to locate more rhodolith beds in the Gulf of California. Frequent rhodolith transport by water motion does not appear necessary for bed development. Therefore, many beds may be located in areas of moderate to low current velocities with gently sloping bottoms, sufficient light, low sedimentation, available source material, and frequent bioturbation.

When using fossil rhodolith beds as indicators of paleo-environments, investigators should be aware that rhodolith presence/absence and rhodolith morphology are not only products of the past water motion regime. In some beds, bioturbation may be of equal if not greater importance than water motion as a mechanism for rhodolith movement. The ability of rhodolith beds to persist in episodic as well as constant water motion conditions also complicates their use in determining past environments. More in depth investigation on rhodolith growth rates, translocation as a mechanism for 
rhodolith survival without movement, and bioturbation affects would shed light on the necessary and actual frequency of rhodolith movement. 


\section{BIBLIOGRAPHY}

Adey, W.H., 1973. Temperature control of reproduction and productivity in a subarctic crustose coralline. Phycologia, Vol. 12, pp. 111-118.

Adey, W.H., and P.J. Adey, 1973. Studies on the biosystematics and ecology of the epilithic crustose corralines of the British Isles. Br. Phycology Journal, Vol. 8, pp. 343-407.

Adey, W.H. and J.M. Vassar. 1975. Colonization, succession, and growth rates of tropical crustose coralline algae (Rhodophyta, Cryptonemiales). Phycologia. Vol 14, pp. 55-69

Adey, W.H. and I. G. MacIntyre, 1973. Crustose coralline algae: a re-evaluation in the Geological Sciences. Geol. Soc. Am. Bull., Vol. 84, pp. 883-904.

Adey, W.H., and D.L. McKibbon, 1970. Studies on the maerl species Phymatolithon calcareum Pallus (nov.comb.) andLithothamnium corallioides Crouan in the Ria de Vigo. Bot. Marin., Vol. 13, pp. 100-106.

Airy, G.B. 91845). Tides and Waves. Encyclopedia Metrop. Art., Vol. 192, pp. 241-396.

Alvarez-Borrego, S., 1983. Gulf of California. In, Ecosystems of the World, edited by B.H. Ketchum, Elsevier Scientific, New York. Pp. 883-904.

Bandan-Dangon, A., C.E. Dorman, M.A. Merrifield. and C.D. Winant, 1991. The lower atmosphere over the Gulf of California. Journal of Geophysical Research, Vol.96, pp. 16,877-16,896.

Bosence, D. 1976. Ecological studies on two unattached coralline algae from western Ireland. Palaeontology , Vol. 19, pp. 365-395.

Bosence, D. 1983a. Description and classification of rhodoliths (rhodoids, rhodolites). In Coated Grains, edited by T.M. Peryt ,Springer-Verlag, Berlin, Germany, pp. 217-224

Bosence, D. 1983b. The occurrence and ecology of recent rhodoliths (rhodoids, rhodolites). In Coated Grains, edited by T.M. Peryt, Springer-Verlag, Berlin, Germany, pp. 217-224 
Bosence, D. 1985. The morphology and ecology of a mound-building coralline alga (Neogoniolithon strictum) from the Florida Keys. Palaeontology, Vol.28, pp. 189-206.

Bosence, D. and H. Pedley, 1982. Sedimentology and paleoecology of a Miocene coralline algal biostrome from the Maltese Islands. Palaeogeo., Palaeoclim., Palaeoeco., Vol.38, pp.9-43.

Bosellini, A. and R. Ginsburg. 1971. Form and internal structure of recent algal nodules (Rhodolites) from Bermuda. Journal of Geology, Vol. 79, pp. 669-682.

Braga, J.C. and J.M. Martin, 1988. Neogene coralline-algal growth-forms and their paleoenvironments in the Almanzora River Valley (Almeria, S.E. Spain). Paleogeo., Paleoclim., and Paleoecol., Vol. 67, pp. 285-303.

Candella, J., A. Bandan-Dangon and C.D. Winant, 1984. Spatial distribution of lower atmospheric physical variables over the Gulf of California. A data report. Volume 1. Summer 1983, Scripps Institute of Oceanography Reference Series, \# 84-33., La Jolla, California, 211 pp.

Candella, J., A. Bandan-Dangon and C.D. Winant, 1985. Spatial distribution of lower atmospheric physical variables over the Gulf of California. A data report. Volume 1. Winter 1984, Scripps Institute of Oceanography Reference Series, \# 85-11., La Jolla, California, 303 pp.

Cardenas, L.A., J. R. Romero, and F.G. Magana, 1990. Observaciones troficas de tres especies de peces de importancia comerceal de Bahia Concepcion, Baja California Sur, Mexico. Inv. Mar. CiCiMar, Vol. 5, pp.55-61.

Carney, R.S., 1981. Bioturbation and biodisposition, in Principles of benthic Marine Paleoecology edited by Arthur J. Boucot, Academic Press, New York, pp 357-389.

Davies, A.G., 1980. Field observations of the threshold of sand motion in a transitional wave boundary layer. Coastal Eng., Vol. 4, pp.23-46.

Dawson, E.Y.,1960. Marine red algae of Pacific Mexico. Part 3. Cryptonemiales, Corallinaceae subf Melobesioideae. Pacific Naturalist, Vol. 2, pp. 3-125.

Denny, M.W., 1988, Biology and the Mechanics of the Wave Swept Environment., Princeton Univ. Press, Princeton, New Jersey, 329p. 
Dyer, K.R., 1986, Coastal and Estuarine Sediment Dynamics, John Wiley and Sons Ltd., New York, New York.

Edyvean, R.G.H. and H. Ford. 1987. Growth rates of Lithophylum incrustans (Corallinales, Rhodophyta) from Southwest Wales. British Phycological Journal, Vol. 22, pp.139-146.

Flores-Ramirez, S., 1994, Utilizacion ecologica de La Bahia de La Paz, Baja California Sur por el rorcual tropical Balaenoptera edeni (Cetacea: Balaenopteridae), 1988-1991 [Tesis de Maestro en Ciencias]: Ensenada, Universidad Autonoma de Baja California, 93 p.

Foster, M.S., R.Riosmena-Rodriguez, D. Stellar, W. Woelkerling. Living rhodolith beds in the Gulf of California and their implications for paleoenvironmental interpretation. In Pliocene Carbonates and Related Facies Flanking the Gulf of California, Baja California Sur, Mexico. (eds. M.E. Johnson and J. Ledesma-Vazquez). GSA Special Publication 318 (in press).

Freiwald, A., R. Heinrich, P. Schafer, and H. Willkomm, 1991. The significance of high-boreal to subarctic maerl deposits in Northern Norway to reconstruct Holocene climactic changes and sea level oscillations. Facies, Vol.25, pp.315-340.

Freiwald, A. 1993. Coralline algal maerl frameworks - islands within the Phaeophytic kelp belt. Facies, Vol. 29, pp.133 - 148.

Freiwald, A. 1995. Sedimentological and biological aspects in the formation of branched rhodoliths in northern Norway. Beitr. Palaont. Vol. 20 WEIN, pp. 7-9.

Harris, P.T., Y. Tsuji, J.F. Marshall, P.J. Davies, N. Honda, and H. Matsuda, 1996. Sand and rhodolith-gravel entrainment on the mid- to outershelf under a western boundary current: Fraser Island continental shelf, eastern Australia. Marine Geology Vol. 129, pp. 313-330.

Hjulstrom, F. , 1939. Transportation of detritus by moving water. In Recent Marine Sediments, edited by P.D. Trask, Amer. Assoc. Petrol. Geol. (reprinted by dover in 1955), pp. 5-31.

Holmes, R.W., 1970, The secchi disk in turbid coastal waters: Limnology and Oceanography, Vol. 15, pp. 688-694. 
Inman D. L., 1949. Sorting of sediments in the light of fluid mechanics. Journal of Sed. Pet., Vol. 19, pp. 51-70.

Kendrick, G. 1991. Recruitment of coralline crusts and filamentous turf algae in the Galapagos Archipelago: effect of simulated scour, erosion, and accretion. Journal of Exp. Mar. Biol. Ecol., Vol. 147, Pp. 47-63.

Kinsman, B., 1965. Wind Waves. Prentice-Hall, Inc., Englewood Cliffs, New Jersey, $676 \mathrm{pp}$.

Knauss, J.A., 1978. Introduction to Physical Oceanography, Prentice-Hall, Inc., Englewood Cliffs, New Jersey, 338 p.

Komar, P.D. and M.C. Miller, 1973.The threshold of sediment movement under oscillatory water waves. J. of Sed. Petrol., Vol. 43(4), pp.1101-1110

Lechuga-Deveze, C.H., 1994, Shift of acetone-extracted pigments due to unknown natural phytoplankton populations for Conception Bay, Gulf of California: Bulletin of Marine Science, Vol. 55, pp. 248-255.

Littler, M.M., Littler, D.S., Blair, S.M., and J.N. Norris. 1985. Deepest known plant life discovered on uncharted seamount. Science, Vol. 227, pp. 5769.

Littler, M., D. Littler, and M. Hanisak. 1991. Deep-water rhodolith distribution, productivity, and growth history at sites of formation and subsequent degradation. Journal of Exp. Mar. Biol. Ecol., Vol.150, pp. 163-182.

Luekart, P. 1994. Field and laboratory studies on depth dependence, seasonality and light requirements of growth in three species of crustose coralline algae (Corallinales, Rhodophyta). Phycologia, Vol.33, pp. 281-290.

Luning, K. 1990. Seaweeds: Their Environment, Biogeography, and Ecophysiology John Wiley and Sons, Inc., New York, 527 p.

Matsuda S. 1989. Succession and growth rates of encrusting crustose coralline algae (Rhodophyta, Cryptonemailes) in the upper fore-reef environment off Ishigaki Island, Ryukyu Islands. Coral Reefs, Vol. 7, pp. 185-195.

McMaster, R.L. and J. T.Conover, 1966.Recent algal stromatolites from the Canary Islands. Journal of Geol., Vol 74, pp. 647-652. 
Merrifield, M.A., A. Badan-Dangon, and C.D. Winant, 1987. Temporal behavior of lower atmospheric variables over the Gulf of California. 1983-1985. A data report. Scripps Institute of Oceanography, Reference Series \#87-6, La Jolla, California. 192pp.

Miles, A.K. and E.C. Meslow. 1990. Effects of experimental overgrowth on the survival and change in the turf assemblage of a giant kelp forest. Journal of Exp. Mar. Biol. Ecol., Vol. 135, pp. 229-242.

Miller, M.C., I.N. McCave, and P.D. Komar ,1977. Threshold of sediment motion under unidirectional currents. Sedimentology, Vol.24, pp. 507527.

Minnery, G.A., 1990. Crustose coralline algae from the Flower Garden Banks, northwestern Gulf of Mexico: controls on distribution and growth morphology. Journal of Sed. Petrol., Vol. 60, pp. 992-1007.

Minoura, K. and T. Nakamori, 1982. Depositional environment of algal balls in the Ryukyu Group. Ryukyu Islands, Southwestern Japan. Journal of Geol., Vol. 90, pp. 602-609.

Myrick, J.L. and K.W.Flessa, 1996.Bioturbation Rates in Bahia la Choya, Sonora, Mexico. Ciencias Marinas, Vol 22(1), pp. 23-46.

N.O.A.A. 1992-1995. Tide Tables of the West Coast of North and South America., Dept. of Commerce, U.S.A.

Obeso-Nieblas, M., A.R. Illescas, and S.Dieguez, 1993. Modelacion de la marea en la Bahia de la Paz, B.C.S. Inv. Mar. CICIMAR, Vol. 8, pp. 13-22.

Prager, E.J. and Ginsburg, 1989. Carbonate nodule growth on Florida's outer shelf and its implications for fossil interpretation. Palaios, Vol. 4, pp. 310-317.

Reid, R.P. and I.G. MacIntyre, 1988. Foraminiferal-algal nodules from the eastern Carribean: growth history and implications on the value of nodules as paleoenvironmental indicators. Palaios, Vol. 3. pp. 424-435.

Roden, G.I., 1964. Oceanographic aspects of Gulf of California.In Marine Geology of the Gulf of California, edited by Van Andel T. and G. Shor, Am. Assoc. Petrol. Geol. Mem. 3 : 59-75. 
Rodriguez-Romero, J., L. A. Cardenas, F.Magana, and H. Ramos, 1994. Composition, abundance and specific richness of fishes from Concepcion Bay, Baja California Sur, Mexico. Ciencias Marinas, Vol. 20(3), pp. 321-350

Scoffin, T.P., D.R. Stoddart, A.W. Tudhope, and C. Woodroffe, 1985. Rhodoliths and coralliths of Muri Lagoon, Rarotonga, Cook Islands. Coral Reefs, Vol.4, pp.71-80.

Sheilds, A., 1936. Anwendung der ahnlichkeits mechanik und der turbulenzforschung auf die geschiebe bewegung :Preuss. Versuchanstalt fur Wasserbau und Schiffbau, Berlin, 20 p.

Stellar, D. L., 1993, Ecological Studies of Rhodoliths in Bahia Concepcion,Baja California Sur, Mexico M.S. Thesis, California State University, Moss Landing Marine Laboratory, 89p.

Stellar, D.L., and M.S. Foster, 1995. Environmental factors influencing the distribution and morphology of rhodoliths in Bahia Concepcion, B.C.S., Mexico. Journal of Experimental Marine Biology and Ecology. Vol. 194 ,pp. 201-212.

Steneck, R.S., 1986. The ecology of coralline algal crusts: convergent patterns and adaptive strategies. Ann. Rev. Ecol. Syst. , Vol. 17, pp. 273-303.

Sternberg, R.W.,1971.Measurements of incipient motion of sediment particles in the marine environment. Marine Geology, Vol. 10, pp.113-119.

Studencki, W., 1979. Sedimentation of algal limestones from Busko-Spa Environs (Middle Miocene, Central Poland). Paleogeo, Paleoclim., Paleoeco.. Vol.27, pp. 155-165.

Sundborg, A., 1956. The River Klaralven: A study of fluvial processes: Geograf. Ann., Vol.38, pp. 127-316.

Trush, S.F., R.D. Pridmore, J.E. Hewitt, and V.J.Cummings, 1991. Impact of ray feeding disturbances on sandflat macrobenthos: Do communities dominated by polycheates or shellfish react differently? Mar. Ecol. Prog. Ser., Vol.69 (3), pp. 245-252. 
Tsuji, Y., 1993. Tide influenced high energy environments and rhodolithassociated carbonate deposition on the outer shelf and slope off the Miyako Islands, southern Ryukyu Island Arc, Japan. Marine Geology, Vol. 113, pp. 255-271.

Underwood, A.J., 1981. Techniques of analysis of variance in experimental marine biology and ecology. Oceanogr. Mar. Biol. Ann. Rev. Vol.19, pp.513-605.

U.S. Army Corps of Engineers, 1984. Shore Protection Manual, Vol 1., Fourth ed.,Coastal Engineeering Research Center, Dept. of the Army, U.S. Govt Printing Office, Washington D.C.

Woelkerling, Wm. J., L.M. Irvine, and A.S. Harvey, 1993. Growth-forms in non-geniculate coralline red algae (Corallinales, Rhodophyta):

Australian Systematic Botany, V. 6, p 277-293.

Zar, J.H., 1984. Biostatistical Analysis. Prentice-Hall, Inc., Englewood Cliffs, New Jersey, $718 \mathrm{p}$. 
Table 1: Rhodolith movement and wind conditions observed during a range of current velocities at the El Requeson wave bed, the Punta Bajo Channel, and the San Lorenzo Channel.

\begin{tabular}{|c|c|c|c|c|c|c|c|c|c|}
\hline $\begin{array}{l}\text { Date \& } \\
\text { Time }\end{array}$ & $\begin{array}{l}\text { Sample } \\
\text { Location }\end{array}$ & $\begin{array}{l}\text { \# of } 1 / 2 \\
\text { sec } \\
\text { samples }\end{array}$ & $\begin{array}{l}\text { Max. } \\
\text { Velocity } \\
\mathrm{cm} / \mathrm{sec}\end{array}$ & $20-$ & $\begin{array}{l}\text { reque } \\
25- \\
30\end{array}$ & $\begin{array}{l}\text { cey }(\mathrm{cm} \\
30- \\
35\end{array}$ & $\begin{array}{l}75) \\
35- \\
40\end{array}$ & $\begin{array}{l}\text { Rhodolith } \\
\text { movement }\end{array}$ & $\begin{array}{l}\text { Wind } \\
\text { condition }\end{array}$ \\
\hline $1 / 23 / 96$ & Requesion & & & & & & & & \\
\hline $\begin{array}{l}\text { 10:00 } \\
11: 00\end{array}$ & & $\begin{array}{l}360 \\
360\end{array}$ & $\begin{array}{l}20.7 \\
26.8\end{array}$ & $\begin{array}{l}1 \\
18\end{array}$ & $\dot{3}$ & $\begin{array}{l}- \\
-\end{array}$ & - & $\begin{array}{l}\text { none } \\
\text { rocking; }\end{array}$ & $6-9 \mathrm{~m} / \mathrm{s}$ \\
\hline $12: 00$ & & 360 & 29.0 & 16 & 2 & - & - & $\begin{array}{l}<2 \mathrm{~cm} \text { plants rolling } \\
\text { steady, vigorous } \\
\text { rocking }\end{array}$ & $315^{\circ} \mathrm{NW}$ \\
\hline $13: 00$ & & 360 & 28.1 & 18 & 6 & - & - & $\begin{array}{l}\text { steady rocking; } \\
<2 \mathrm{~cm} \text { plants rolling }\end{array}$ & \\
\hline $14: 00$ & & 360 & 30.9 & 24 & 17 & 1 & - & $\begin{array}{l}\text { steady rocking; } \\
<2 \mathrm{~cm} \text { plants rolling }\end{array}$ & $\begin{array}{l}0600 \mathrm{hrs} \\
\text { to }\end{array}$ \\
\hline $15: 00$ & & 360 & 29.8 & 20 & 9 & - & - & steady rocking & 2200 \\
\hline $16: 00$ & & 360 & 37.9 & 19 & 3 & 3 & 1 & steady rocking & \\
\hline $17: 00$ & & 360 & 28.0 & 12 & 1 & - & - & steady rocking & \\
\hline 18:00 & & 360 & 38.0 & 14 & 9 & 1 & 1 & $\begin{array}{l}\text { rocking; } \\
<=5 \mathrm{~cm} \text { plants rolling }\end{array}$ & \\
\hline 19:00 & & 360 & 25.2 & 11 & 1 & 0 & - & none & \\
\hline $\begin{array}{c}20: 00 \text { to } \\
1 / 24 / 96 \\
03: 00 \\
\end{array}$ & & 3240 & 28.8 & 10 & 2 & - & - & none & \\
\hline $2 / 4 / 96$ & Requesion & & & & & & & & \\
\hline 13:00 & & 600 & 22.2 & 2 & - & - & - & some rocking & $5-7 \mathrm{~m} / \mathrm{s}$ \\
\hline $14: 00$ & & 600 & 16.2 & - & - & - & - & some rocking & \\
\hline $15: 00$ & & 600 & 26.2 & 10 & 2 & - & - & rocking; rolling & $310^{\circ} \mathrm{NW}$ \\
\hline $16: 00$ & & 600 & 33.5 & 35 & 13 & $t$ & - & $\begin{array}{l}\text { heavy rocking; } \\
<2 \mathrm{~cm} \text { plants rolling }\end{array}$ & \\
\hline $17: 00$ & & 600 & 45.2 & 53 & 26 & 13 & 6 & $\begin{array}{l}\text { heavy rocking; } \\
<3 \mathrm{~cm} \text { plants rolling }\end{array}$ & -1200 to \\
\hline 18:00 & & 600 & 35.9 & 32 & 9 & 0 & $\begin{array}{l}0 \\
1> \\
40 \\
\mathrm{~cm} / \mathrm{s}\end{array}$ & rocking & $2200 \mathrm{hrs}$ \\
\hline $\begin{array}{l}19: 00 \\
20: 00 \\
\end{array}$ & & $\begin{array}{l}600 \\
600\end{array}$ & $\begin{array}{l}25.9 \\
24.8\end{array}$ & $\begin{array}{l}6 \\
2\end{array}$ & 2 & - & & end video & \\
\hline $\begin{array}{r}21: 00 \\
\text { to } 24: 00\end{array}$ & & 2400 & 10.8 & - & - & - & - & & \\
\hline $\begin{array}{c}2 / 3 / 96 \\
15: 18 \text { to } \\
2 / 4 / 96 \\
01: 18\end{array}$ & Requeson & 7200 & 27.2 & 5 & 1 & - & - & $\begin{array}{l}\text { slight to strong } \\
\text { rocking during late } \\
\text { afternoon during } \\
\text { highest velocities }\end{array}$ & $\begin{array}{l}8 \mathrm{~m} / \mathrm{s} \\
315^{\circ} \mathrm{NW} \\
1300 \text { to } \\
\text { 0200hrs }\end{array}$ \\
\hline
\end{tabular}


Table 1 - continued.

\begin{tabular}{|c|c|c|c|c|c|c|c|c|c|}
\hline $\begin{array}{c}\text { Date \& } \\
\text { Time }\end{array}$ & $\begin{array}{l}\text { Sample } \\
\text { Location }\end{array}$ & $\begin{array}{l}\text { \# of } 1 / 2 \\
\text { sec } \\
\text { samples }\end{array}$ & $\begin{array}{l}\text { Max. } \\
\text { Velocity } \\
\mathrm{cm} / \mathrm{sec}\end{array}$ & $\begin{array}{ll}20- & F \\
25 & \\
\end{array}$ & \begin{tabular}{|l|} 
Frequel \\
$\begin{array}{l}25- \\
30\end{array}$ \\
\end{tabular} & $\begin{array}{l}\mathrm{cyy}(\mathrm{cm} \\
30- \\
35\end{array}$ & \begin{tabular}{|l}
$/ s)$ \\
$35-$ \\
40
\end{tabular} & $\begin{array}{l}\text { Rhodolith } \\
\text { movement }\end{array}$ & $\begin{array}{l}\text { Wind } \\
\text { condition }\end{array}$ \\
\hline $\begin{array}{c}1 / 12 / 96 \\
12: 30 \\
\text { to } 24: 30\end{array}$ & Requeson & 7200 & \begin{tabular}{|l|}
23.1 \\
\end{tabular} & 13 & 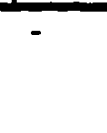 & - & - & none & $\begin{array}{l}1-3 \mathrm{~m} / \mathrm{s} \\
\mathrm{NW}\end{array}$ \\
\hline \begin{tabular}{|c|}
$1 / 14 / 96$ \\
$11: 00$ to \\
$1 / 15 / 96$ \\
$00: 00$ \\
\end{tabular} & Requeson & 5400 & 11.8 & - & - & - & - & none & $\begin{array}{l}1-3 \mathrm{~m} / \mathrm{s} \\
\mathrm{NW}\end{array}$ \\
\hline \begin{tabular}{c|}
$1 / 15 / 96$ \\
$13: 00 t o$ \\
$1 / 16 / 96$ \\
$08: 00$
\end{tabular} & Requeson & 7200 & 14.8 & - & - & - & - & none & $\begin{array}{l}2-5.5 \mathrm{~m} / \mathrm{s} ; \\
310^{\circ} \mathrm{NW} \\
\\
1030 \text { to } \\
1900 \mathrm{hrs} \\
\end{array}$ \\
\hline \begin{tabular}{|c|}
$2 / 1 / 96$ \\
$15: 00 t o$ \\
$2 / 2 / 96$ \\
$02: 00$ \\
\end{tabular} & Requeson & 7200 & 12.2 & - & - & - & - & none & $\begin{array}{l}3-8.7 \mathrm{~m} / \mathrm{s} ; \\
\text { variable } \\
\text { direction } \\
\text { all day. } \\
\end{array}$ \\
\hline \begin{tabular}{|c|}
$2 / 14 / 96$ \\
$13: 00$ to \\
$2 / 15 / 96$ \\
$12: 00$ \\
\end{tabular} & $\begin{array}{l}\text { San } \\
\text { Lorenzo }\end{array}$ & $\begin{array}{l}6900 \\
(1 \mathrm{sec} \\
\text { sample) }\end{array}$ & 34.8 & 824 & 270 & 18 & - & none & \\
\hline \begin{tabular}{|c|}
$2 / 16 / 96$ \\
$08: 00$ to \\
$2 / 17 / 96$ \\
$07: 00$ \\
\end{tabular} & $\begin{array}{l}\text { San } \\
\text { Lorenzo }\end{array}$ & $\begin{array}{l}6900 \\
(1 \mathrm{sec} \\
\text { sample) }\end{array}$ & 31.4 & 232 & 116 & 2 & - & none & \\
\hline \begin{tabular}{|c|}
$2 / 17 / 96$ \\
$08: 30 t o$ \\
$2 / 17 / 96$ \\
$19: 40$ \\
\end{tabular} & $\begin{array}{l}\text { San } \\
\text { Lorenzo }\end{array}$ & 7199 & 36.8 & 1380 & 606 & 172 & 4 & none & \\
\hline $\begin{array}{c}1 / 18 / 96 \\
14: 00 \text { to } \\
1 / 19 / 96 \\
14: 00 \\
\end{array}$ & $\begin{array}{l}\text { Punta } \\
\text { Bajo }\end{array}$ & \begin{tabular}{|l|}
2150 \\
$(2 \mathrm{sec}$ \\
sample)
\end{tabular} & \begin{tabular}{|l|}
23.9 \\
\end{tabular} & 24 & - & - & - & none & \\
\hline \begin{tabular}{c|}
$1 / 19 / 96$ \\
$16: 00$ to \\
$1 / 20 / 96$ \\
$07: 00$ \\
\end{tabular} & $\begin{array}{l}\text { Punta } \\
\text { Bajo }\end{array}$ & $\begin{array}{l}2550 \\
(2 \mathrm{sec} \\
\text { sample) }\end{array}$ & 19.5 & - & - & & - & none & \\
\hline \begin{tabular}{|c|}
$1 / 20 / 96$ \\
$09: 00$ to \\
$1 / 20 / 96$ \\
$14: 00$ \\
\end{tabular} & $\begin{array}{l}\text { Punta } \\
\text { Bajo }\end{array}$ & $\begin{array}{l}900 \\
(2 \mathrm{sec} \\
\text { sample) }\end{array}$ & 36.9 & 27 & 14 & 12 & 1 & none & \\
\hline
\end{tabular}


Table 2: a) Analysis of variance for the effect of depth, location (blocked), and rhodolith morphology (small, large, densely branched, open branched) on distance transported. Values used are averages of data sets collected from three movement events between January 23 and February 5, 1996. b). Mean, standard deviation, and range of distance moved $(\mathrm{cm})$ by rhodoliths from initial position after high water motion. Values from $n=27$ (grouping location and three data collections).

a)

\begin{tabular}{lllll}
\hline Source of Variation & $\mathrm{df}$ & $\mathrm{ms}$ & $\mathrm{F}$ & $\mathrm{P}$ \\
\hline Depth[Location] & 1 & 1.999 & 6.828 & 0.01 \\
Location & 2 & 0.005 & 0.016 & 0.98 \\
Morphology & 2 & 0.025 & 0.085 & 0.92 \\
Depth*Morphology & 2 & 0.016 & 0.053 & 0.95 \\
Location*Morphology & 4 & 0.016 & 0.054 & 0.99 \\
Error & 43 & 0.293 & & \\
\hline
\end{tabular}

b)

$\begin{array}{llc}\text { Shallow }(4.5 \mathrm{~m}) & \text { Mean } \pm \text { Std.dev }(\mathrm{cm}) & \text { Range } \\ \text { sparsely branched/small } & 19.6 \pm 25.7 & 0.0-95.0 \\ \text { densely branched/small } & 13.2 \pm 18.1 & 0.0-75.0 \\ \text { large } & 16.5 \pm 18.9 & 0.0-80.0 \\ \text { Deep }(9 \mathrm{~m}) & \text { Mean } \pm \text { Std.dev }(\mathrm{cm}) & \text { Range } \\ & & \\ \text { sparsely branched/small } & 0.2 \pm 0.8 & 0.0-3.0 \\ \text { densely branched/small } & 0.0 & 0.0 \\ \text { large } & 2.0 \pm 5.0 & 0.0-17.0\end{array}$


Table 3: Days at Isla Tortuga that wind blew more than 6 hours, in a consistent $\mathrm{N} / \mathrm{NW}$ direction, at a consistently high velocity (greater than $6 \mathrm{~m} / \mathrm{sec}$ ). This is an estimate of the number of days per month that wind conditions were sufficient to cause wave induced rhodolith movement in the shallow (4-5 m) depths of rhodolith beds in Bahia Concepcion, $85-90 \mathrm{~km}$ to the south. Some months have incomplete records. In some cases, Santa Rosalia records were used to fill in data gaps.

\begin{tabular}{|l|l|l|l|}
\hline $\begin{array}{l}\text { Year/ } \\
\text { Month }\end{array}$ & $\begin{array}{l}\text { Days with wind } \\
\text { event }\end{array}$ & $\begin{array}{l}\text { \% of days out of } \\
\text { total days with } \\
\text { NE-NW wind }\end{array}$ & $\begin{array}{l}\text { Days in month } \\
\text { with records. }\end{array}$ \\
\hline $\mathbf{1 9 8 3}$ & 6 & 66 & 15 incomplete \\
\hline November & 13 & 71 & 31 \\
\hline December & 18 & 90 & 31 \\
\hline $\mathbf{1 9 8 4}$ & 17 & 87 & 29 \\
\hline January & 8 & 68 & 31 \\
\hline February & 6 & 71 & 24 incomplete \\
\hline March & 1 & 16 & 31 \\
\hline April & 0 & 13 & 30 \\
\hline May & 1 & 16 & 31 \\
\hline June & 0 & 18 & 11 incomplete \\
\hline July & 3 & 31 & 16 incomplete \\
\hline August & 6 & 71 & 31 \\
\hline September & 14 & 77 & 30 \\
\hline October & 13 & 94 & 31 \\
\hline November & & 87 & 31 \\
\hline December & 13 & 72 & 25 incomplete \\
\hline 1985 & 11 & 95 & 22 incomplete \\
\hline January & 9 & & \\
\hline February & &
\end{tabular}


Table 4: A comparison of studies on rhodolith threshold velocities.

\begin{tabular}{|c|c|c|c|c|c|c|c|c|}
\hline \multirow[t]{2}{*}{ Author } & \multirow[t]{2}{*}{ Current } & \multirow[t]{2}{*}{ Substrate } & \multirow{2}{*}{$\begin{array}{l}\text { Rhodolith } \\
\text { density }\end{array}$} & \multicolumn{3}{|c|}{ Rhodolith morphology } & \multirow[t]{2}{*}{$Z^{*}$} & \multirow{2}{*}{$\begin{array}{l}\text { Threshold } \\
\text { velocity o }\end{array}$} \\
\hline & & & & $\begin{array}{l}\text { diam- } \\
\text { eter }\end{array}$ & shape & form & & \\
\hline $\begin{array}{l}\text { Bosence } \\
(1976)\end{array}$ & $\begin{array}{l}\text { oscillatory } \\
\text { wave action } \\
\text { in a wave } \\
\text { tank }\end{array}$ & $\begin{array}{l}\text { sand on } \\
\text { flat metal } \\
\text { plate }\end{array}$ & $\begin{array}{l}\text { individual } \\
\text { plants }\end{array}$ & $<5 \mathrm{~cm}$ & $\begin{array}{l}\text { irregular } \\
\text { to } \\
\text { spherical }\end{array}$ & branched & $\begin{array}{l}\text { currents } \\
\text { calculated } \\
\text { from linear } \\
\text { wave } \\
\text { theory } \\
\end{array}$ & $8-20 \mathrm{~cm} / \mathrm{sec}$ \\
\hline $\begin{array}{l}\text { Scoffin } \\
\text { et al. } \\
\text { (1985) }\end{array}$ & $\begin{array}{l}\text { uni- } \\
\text { directional } \\
\text { in a tidal } \\
\text { channel; } \\
\text { rhodoliths } \\
\text { transplanted }\end{array}$ & $\begin{array}{l}\text { coarse } \\
\text { sand and } \\
\text { gravel }\end{array}$ & $\begin{array}{l}\text { individual } \\
\text { plants }\end{array}$ & $-5 \mathrm{~cm}$ & $?$ & $\begin{array}{l}\text { 'massive' } \\
\text { (laminar) } \\
\text { and } \\
\text { branched }\end{array}$ & $5 \mathrm{~cm}$ & $\begin{array}{l}\text { massive } \\
\text { rhodoliths at } \\
80-90 \\
\mathrm{~cm} / \mathrm{sec} \text {; } \\
\text { branched at } \\
30-40 \mathrm{~cm} / \mathrm{sec}\end{array}$ \\
\hline $\begin{array}{l}\text { Harris } \\
\text { et al. } \\
\text { (1996) }\end{array}$ & $\begin{array}{l}\text { Taboratory } \\
\text { flume }\end{array}$ & $\begin{array}{l}\text { flat surface } \\
\text { of coarse to } \\
\text { madium } \\
\text { sand }\end{array}$ & $\begin{array}{l}\text { groups of } \\
\text { rhodoliths } \\
\text { spaced 2-5 } \\
\text { cm apart }\end{array}$ & $\begin{array}{l}2 \mathrm{~cm} \\
\text { and } \\
5 \mathrm{~cm}\end{array}$ & $?$ & Taminar & $100 \mathrm{~cm}$ & $\begin{array}{l}\text { 2cm diam } \\
\text { rhodoliths at } \\
45-60 \mathrm{~cm} / \mathrm{sec} \\
(27-35 \\
\mathrm{cm} / \mathrm{sec}) \\
5 \mathrm{~cm} \text { diam } \\
\text { rhodoliths at } \\
50-80 \mathrm{~cm} / \mathrm{sec} \\
(27-43 \\
\mathrm{cm} / \mathrm{sec})\end{array}$ \\
\hline $\begin{array}{l}\text { ElReq- } \\
\text { ueson }\end{array}$ & $\begin{array}{l}\text { natural } \\
\text { rhodolith } \\
\text { bed in wave } \\
\text { impacted } \\
\text { subtidal } \\
\text { zone; } 5 \mathrm{~m}\end{array}$ & $\begin{array}{l}\text { coarse } \\
\text { sand }\end{array}$ & $\begin{array}{l}\text { framework } \\
\text { of inter- } \\
\text { locking } \\
\text { rhodoliths }\end{array}$ & $24 \mathrm{~cm}$ & $\begin{array}{l}\text { irregular } \\
\text { to } \\
\text { spherical }\end{array}$ & $\begin{array}{l}\text { branched; } \\
\text { fruticose } \\
\text { and some } \\
\text { foliose }\end{array}$ & $75 \mathrm{~cm}$ & $25-35 \mathrm{~cm} / \mathrm{sec}$ \\
\hline $\begin{array}{l}\text { Punta } \\
\text { Bajo and } \\
\text { San } \\
\text { Lorenzo }\end{array}$ & $\begin{array}{l}\text { natural } \\
\text { rhodolith } \\
\text { bed in tidal } \\
\text { channels at } \\
\text { l1m depth. }\end{array}$ & $\begin{array}{l}\text { coarse } \\
\text { sand }\end{array}$ & $\begin{array}{l}\text { framework } \\
\text { of inter- } \\
\text { locking } \\
\text { rhodoliths }\end{array}$ & $2.5 \mathrm{~cm}$ & $\begin{array}{l}\text { mostly } \\
\text { irregular }\end{array}$ & $\begin{array}{l}\text { branched; } \\
\text { primarily } \\
\text { ruticose }\end{array}$ & $75 \mathrm{~cm}$ & $\begin{array}{l}\text { un- } \\
\text { determined } \\
\text { but } \\
>37 \mathrm{~cm} / \mathrm{sec} \\
(20-25 \\
\mathrm{cm} / \mathrm{sec})\end{array}$ \\
\hline
\end{tabular}

* Height off substrate that currents were measured.

o Threshold velocity and (velocity adjusted for $5 \mathrm{~cm}$ off substrate after Harris et al. (1996)). 
Table 5 : Predicted wave characteristics at $12 \mathrm{~m}$ depths under different wind velocities and durations. Predictions made using methods of the U.S. Army Corps of Engineers (1984) and linear wave theory equations (Appendix 2; Denny 1986).

\begin{tabular}{|l|l|l|l|l|l|}
\hline $\begin{array}{l}\text { Wind Speed } \\
(\mathrm{m} / \mathrm{sec})\end{array}$ & $\begin{array}{l}\text { Predicted } \\
\text { significant } \\
\text { wave height } \\
(\mathrm{m})\end{array}$ & $\begin{array}{l}\text { Predicted } \\
\text { wave period } \\
(\mathrm{sec})\end{array}$ & $\begin{array}{l}\text { Predicted } \\
\text { wave length } \\
(\mathbf{m})\end{array}$ & $\begin{array}{l}\text { Predicted } \\
\text { maximum } \\
\text { particle } \\
\text { velocity } \\
(\mathrm{cm} / \mathrm{sec})\end{array}$ & $\begin{array}{l}\text { Minimum } \\
\text { fetch }(\mathrm{km})\end{array}$ \\
\hline
\end{tabular}

\section{5 hour wind duration}

\begin{tabular}{|l|l|l|l|l|l|}
\hline 5 & 0.75 & 4.3 & 23 & 3 & 35 \\
\hline 10 & 1.1 & 4.8 & 28 & 9 & 45 \\
\hline 15 & 1.6 & 5.6 & 33 & 18 & 50 \\
\hline 24 & 2.5 & 6.0 & 36 & 30 & 60 \\
\hline
\end{tabular}

10 hour wind duration

\begin{tabular}{|l|l|l|l|l|l|}
\hline 5 & 1.1 & 5.5 & 32 & 13 & 100 \\
\hline 10 & 2.0 & 7 & 42 & 31 & 120 \\
\hline 15 & 2.8 & 8 & 48 & 47 & 150 \\
\hline 24 & 5.0 & 10 & 61 & 81 & 175 \\
\hline
\end{tabular}




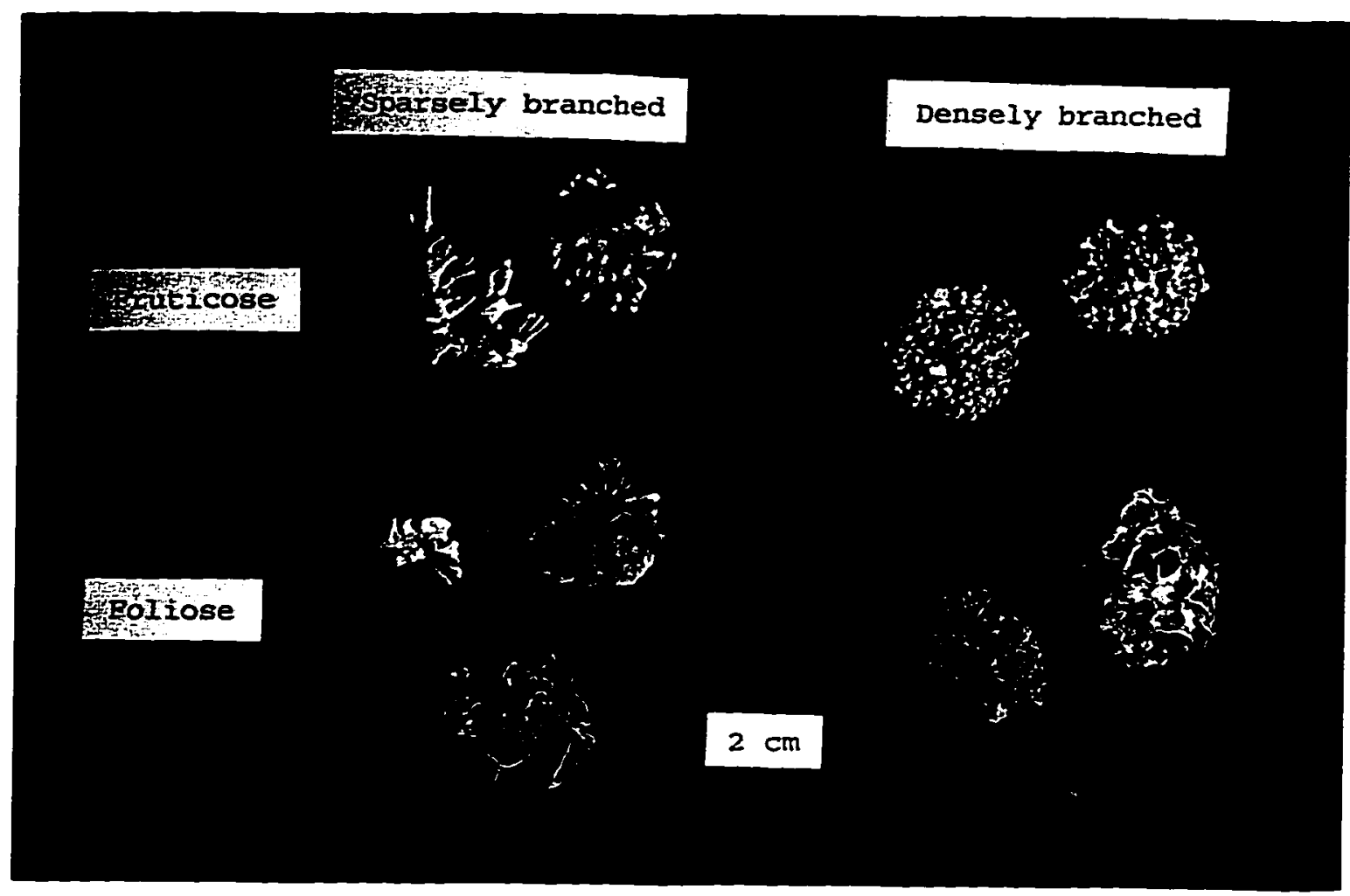

Figure 1: Some common branch morphologies of rhodoliths in the southwestern Gulf of California. Predominantly Lithophyllum Margariti. 


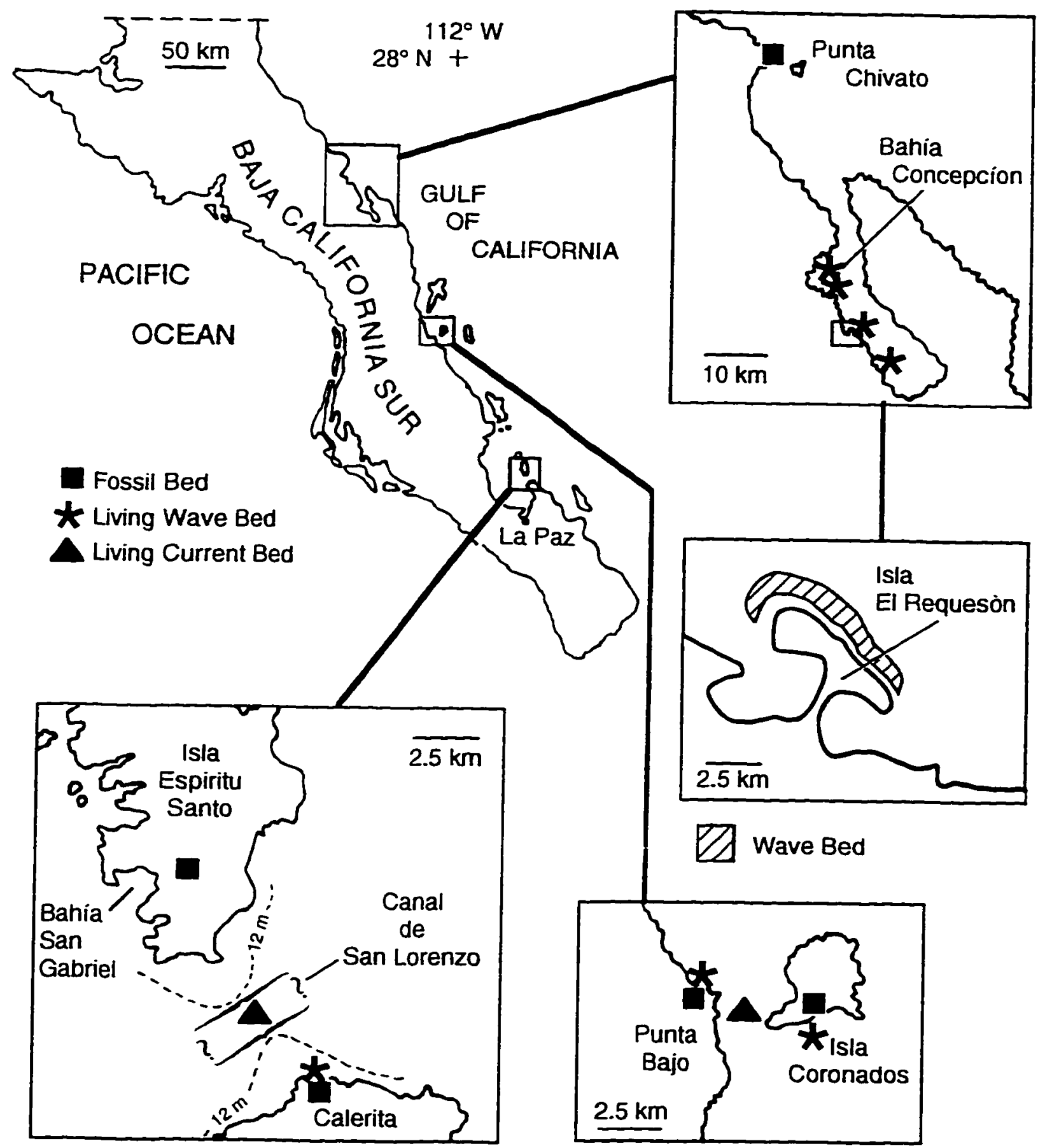

Figure 2: Fossil and living rhodolith beds in the southwestern Gulf of California. Sites investigated were the current beds off Punta Bajo and in the Canal de San Lorenzo and the wave bed off of Isla el Requeson. 


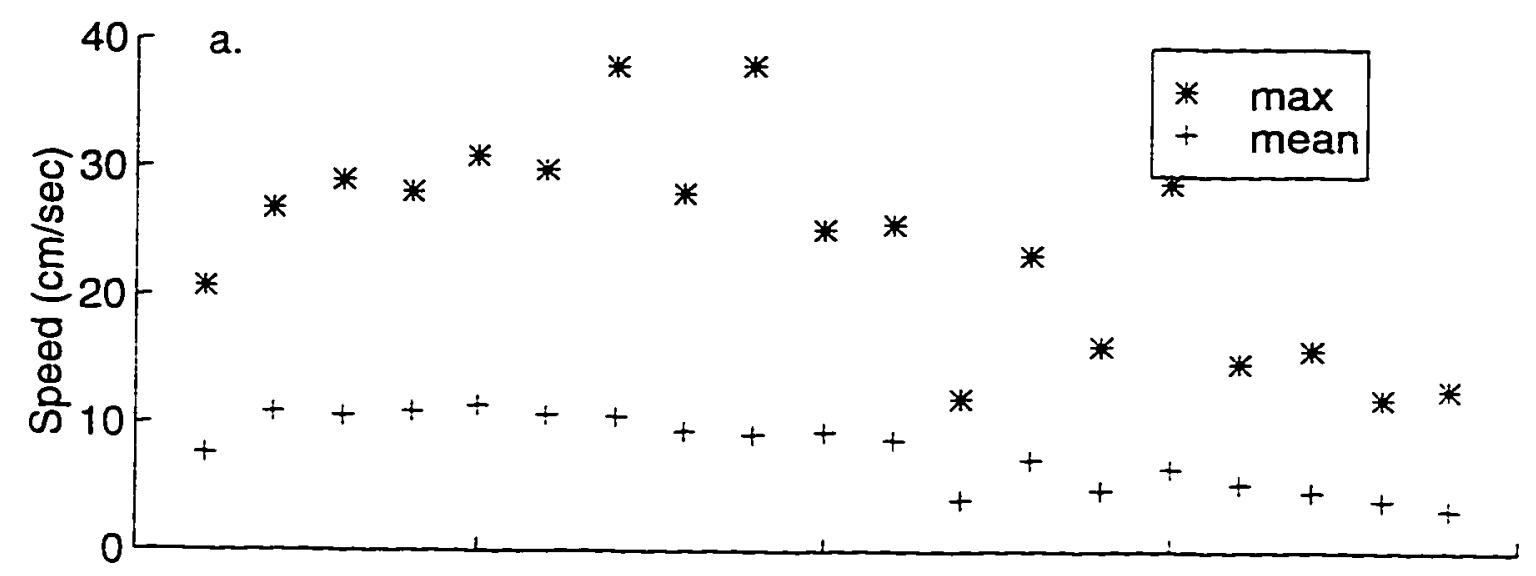

b.

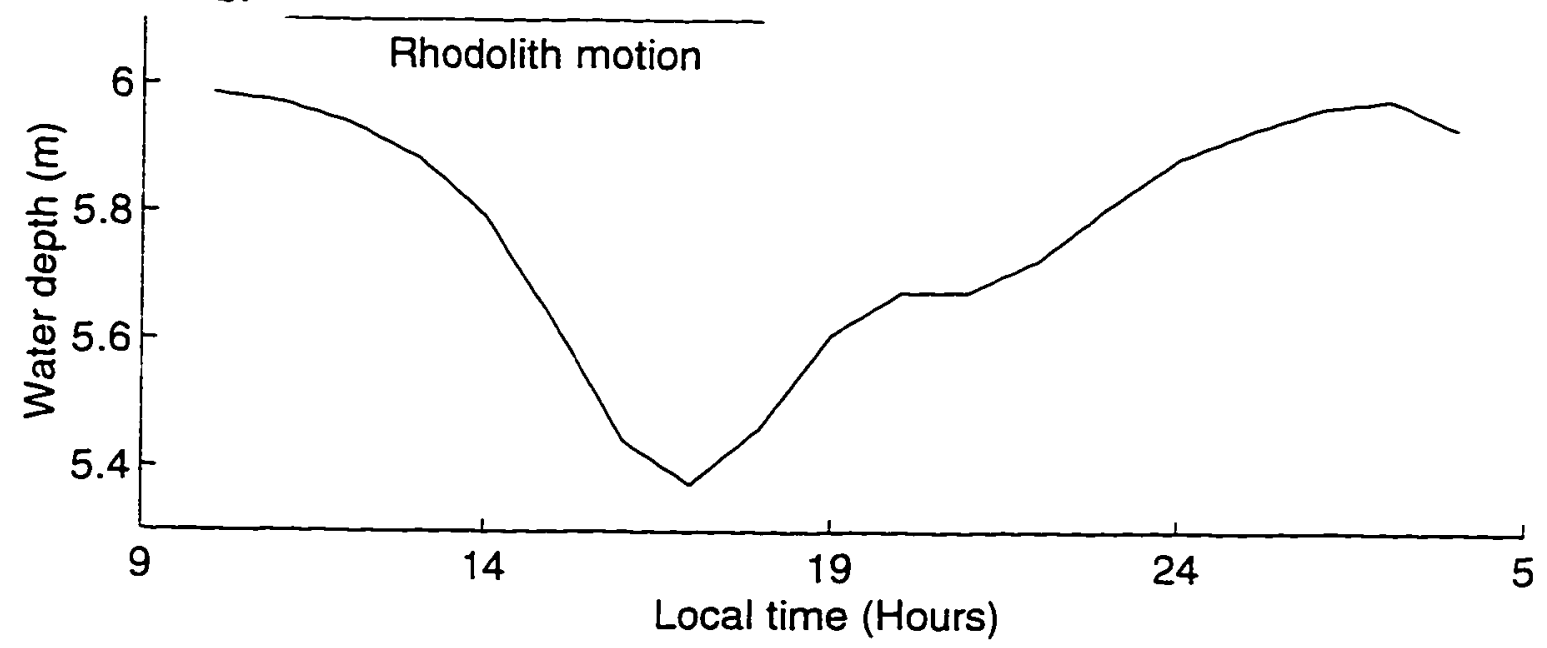

Figure 3: a) The maximum and mean current speeds from 1000 hrs, January 23. 1996 to 0600 hrs. January 24.1996 at El Requeson rhodolith beds measured $0.75 \mathrm{~m}$ above the seafloor at $4.5 \mathrm{~m}$ depth. b) Average tidal height during the same time series. For both current and tide data $n=3600.5 \mathrm{sec}$ samples taken every hour. Rhodolith motion occurred from 1100 to $1800 \mathrm{hrs}$. 
a.

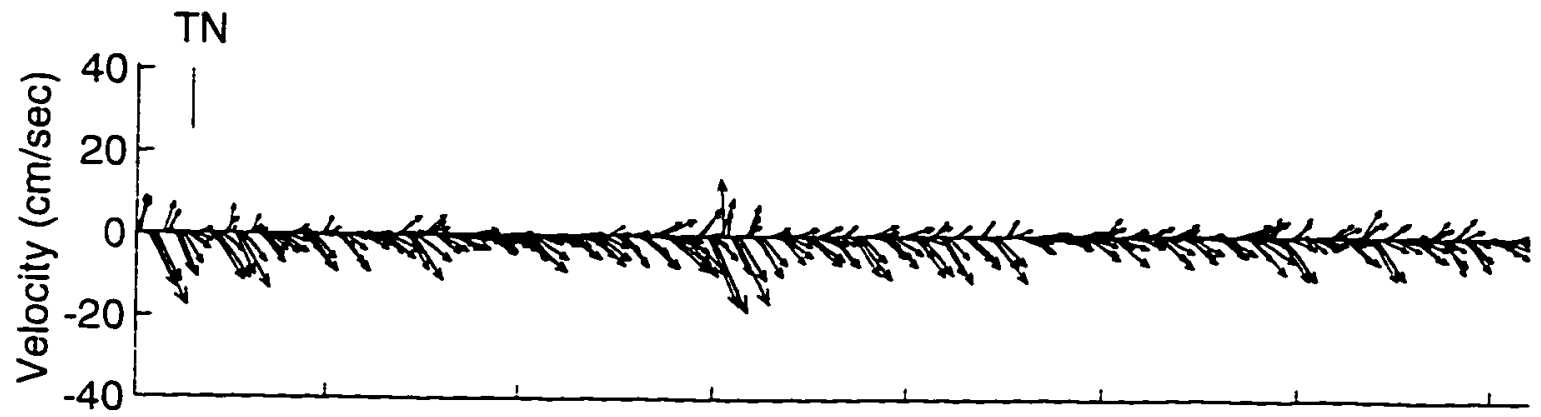

b.

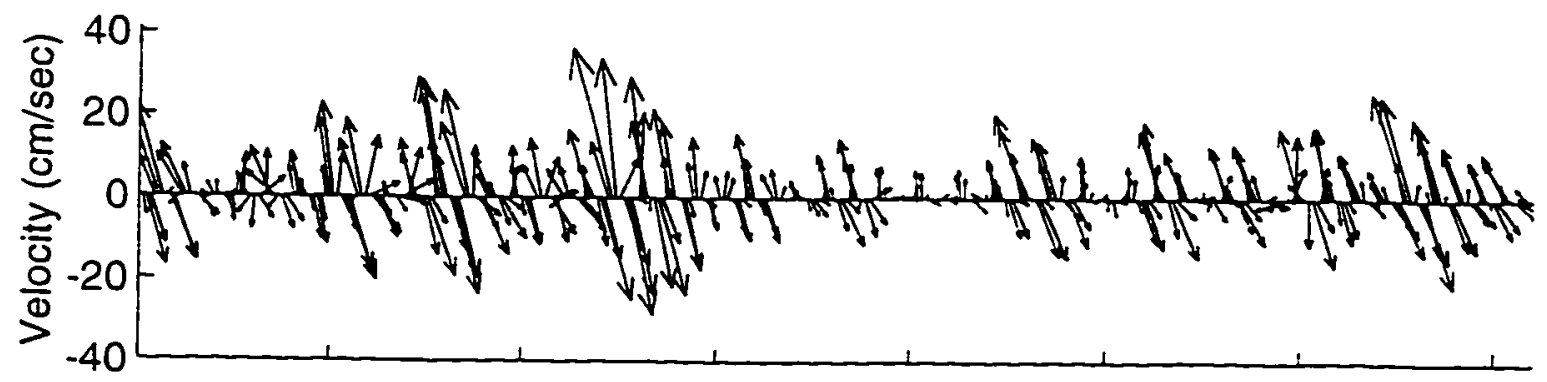

c.

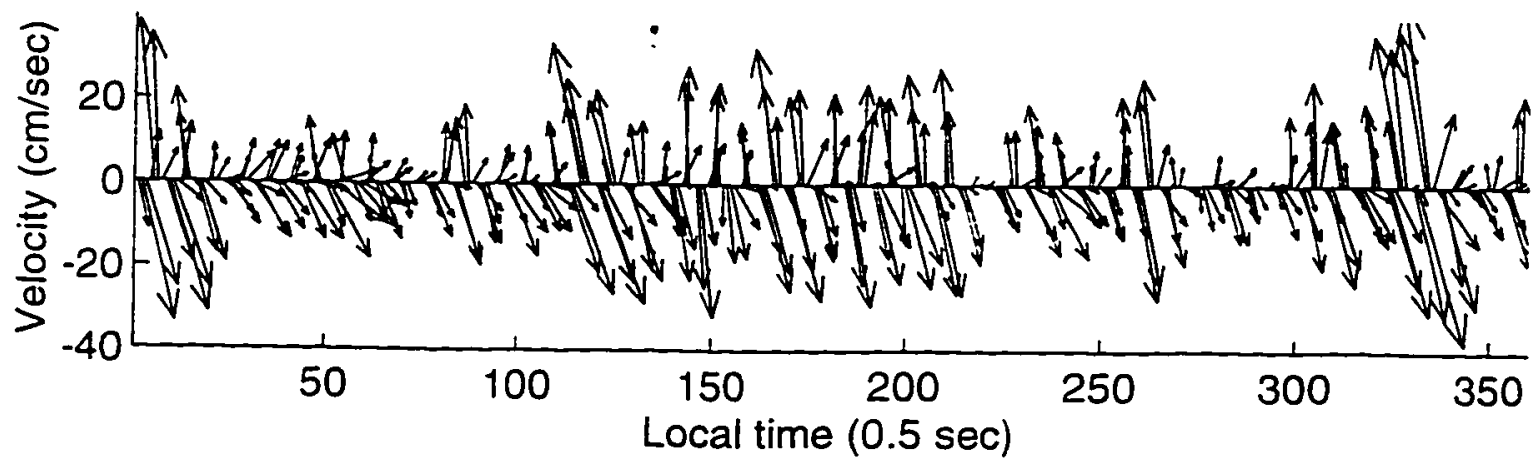

Figure 4: The direction and magnitude of oscillatory wave currents over $4.5 \mathrm{~m}$ deep rhodolith beds at El Requeson for 3 minutes of time. a) Measured at $1000 \mathrm{hrs}$ on January 23. 1996 when no rhodolith movement was observed. b) Measured at 1800 hrs on January 23. 1996 when rhodolith were observed rocking and rolling. c) Measured at 1700 hrs on February 4. 1996 when rhodoliths were observed rocking and rolling. Oriented to true north (TN). 

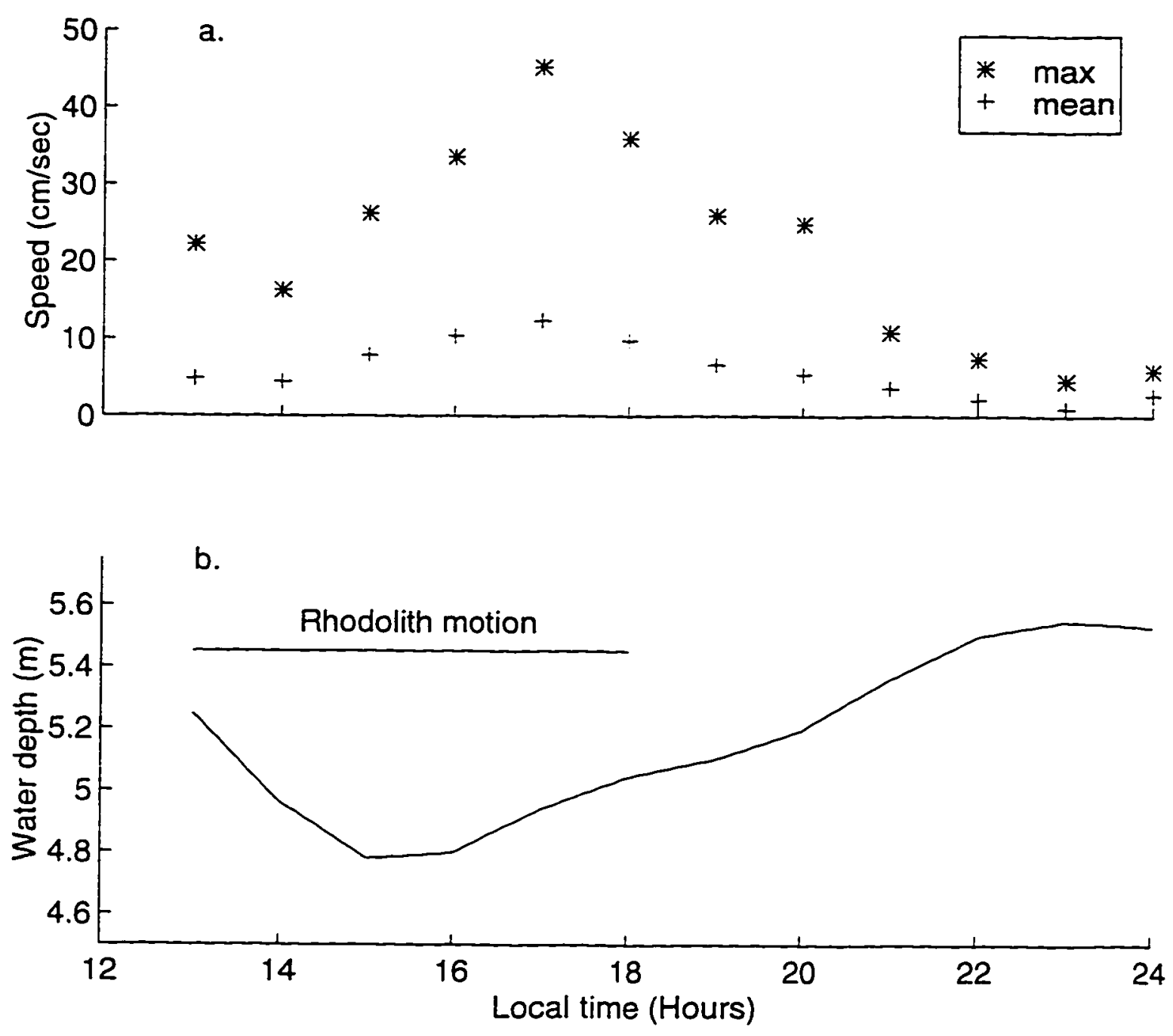

Figure 5: a) The maximum and mean current speeds from 1300 to 2400 hrs. February 4. 1996 at El Requeson rhodolith beds measured $0.75 \mathrm{~m}$ above the seafloor at $4.5 \mathrm{~m}$ depth. b) Average tidal height during the same time series. For both current and tide data $n=6000.5 \mathrm{sec}$ samples taken every hour. Rhodolith motion occurred from 1300 to $1800 \mathrm{hrs}$. 

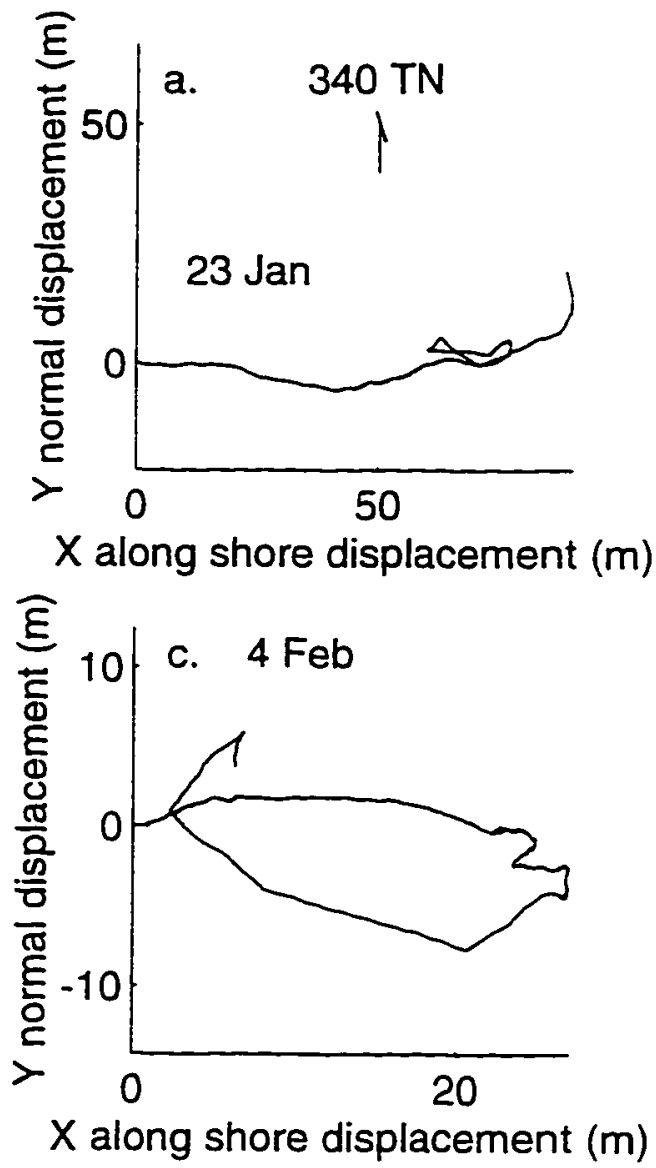
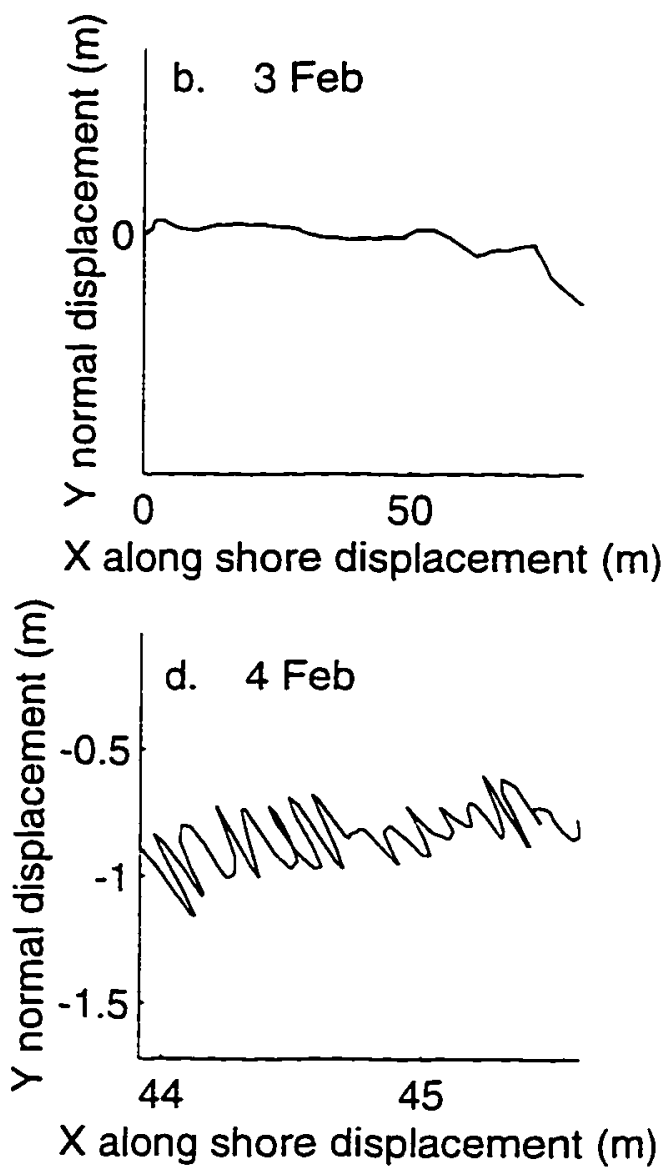

Figure 6: The cumulative displacement of water through time over rhodolith beds at El Requeson. Bahia Concepcion. Directions are relative to $340^{\circ}$ true north (TN) so that "y normal" is roughly perpendicular to shore and " $x$ " is alongshore. a) 1000 hrs. January 23. 1996 to 0600 hrs. January 24.1996 during strong wave action. b) $1500 \mathrm{hrs}$. February 3. 1996 to 0300 hrs. February 4. 1996 during strong wave action. c) 1300 $2400 \mathrm{hrs}$. February 4, 1996 initially strong wave action dies and longshore current strays. d) A one minute sample from figure b) during highest afternoon waves showing oscillatory onshore current. All data measured $0.75 \mathrm{~m}$ above the seafloor at $4.5 \mathrm{~m}$ depth. 


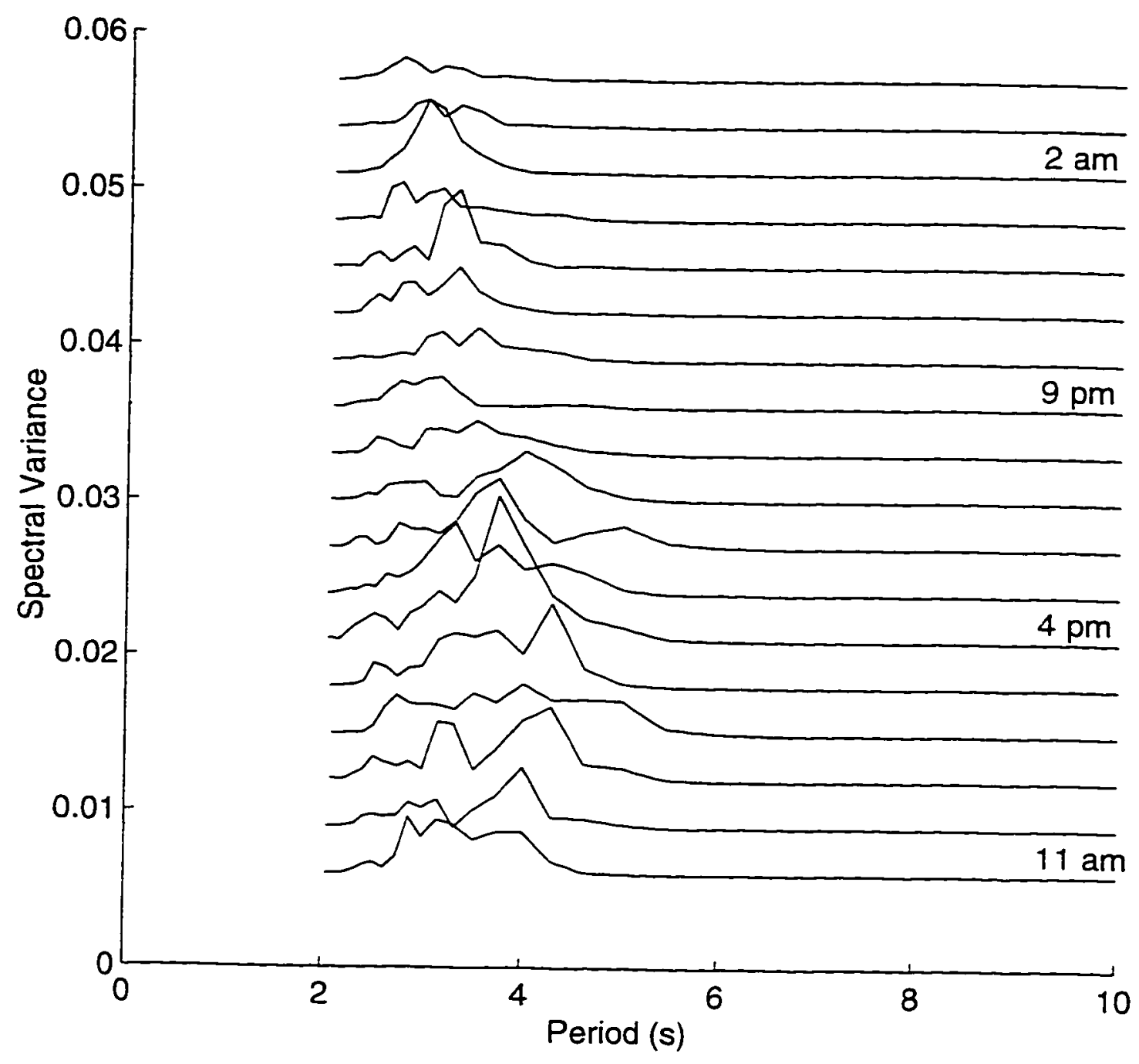

Figure 7: The hourly average period of wind propagated surface waves from $1100 \mathrm{hrs}$ to 0400 hrs (January 23-24, 1996) over rhodolith beds at El Requeson. Bahia Concepcion. Period is calculated from spectral analysis of pressure transducer data collected at a $4.5 \mathrm{~m}$ depth. 

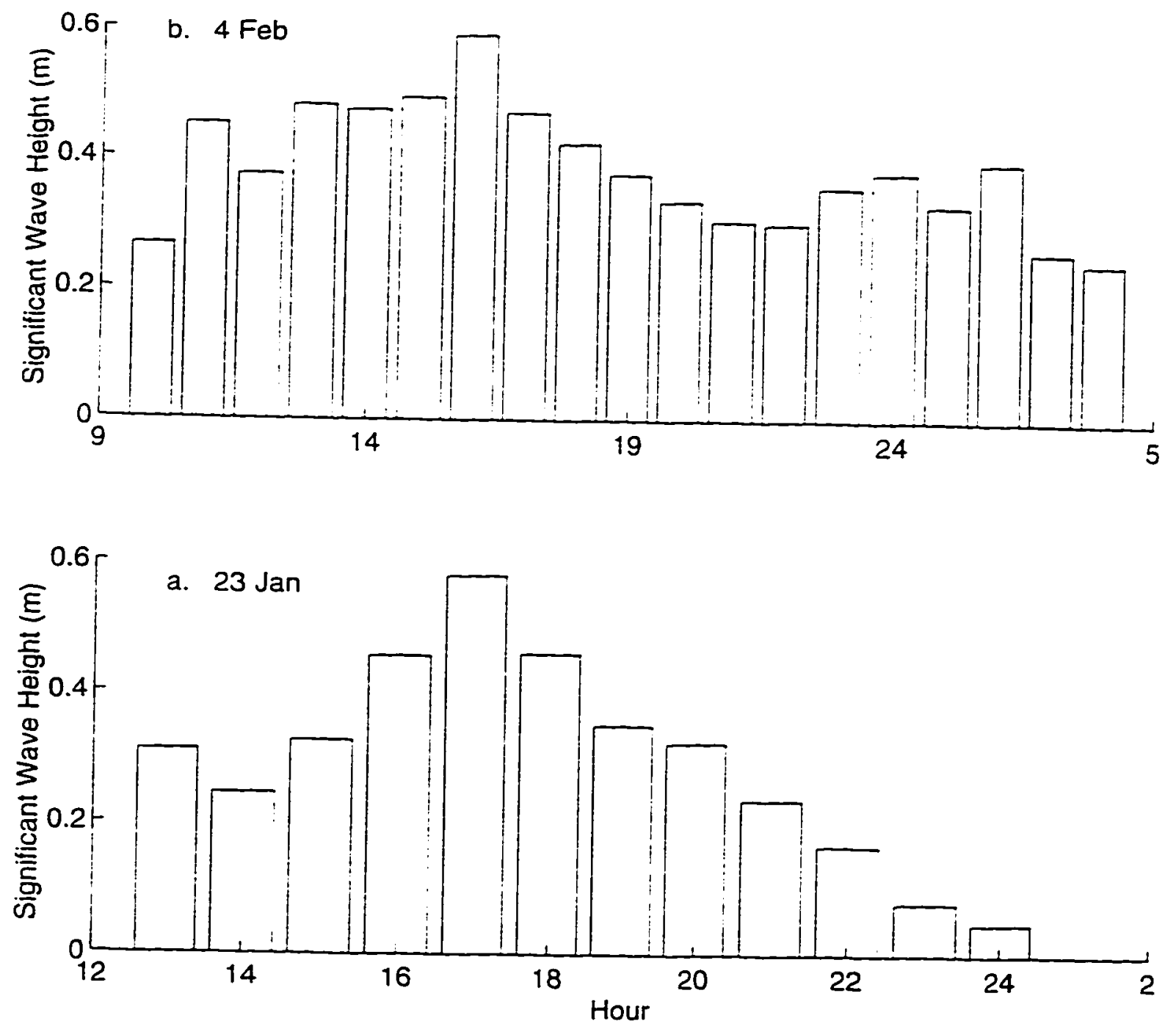

Figure 8: The average significant wave heights $\left(\mathrm{H}_{\mathrm{s}}\right)$ every hour from a) $1000 \mathrm{hrs}$, January 23.1996 to 0600 , January 24. 1996 and b) $1300 \mathrm{hrs}$ to $2400 \mathrm{hrs}$, February 4. 1996. over rhodolith beds at El Requeson. Bahia Concepcion. $\mathrm{H}_{\mathrm{s}}$ calculated from spectral analysis of pressure transducer data collected at $4.5 \mathrm{~m}$ depth. 


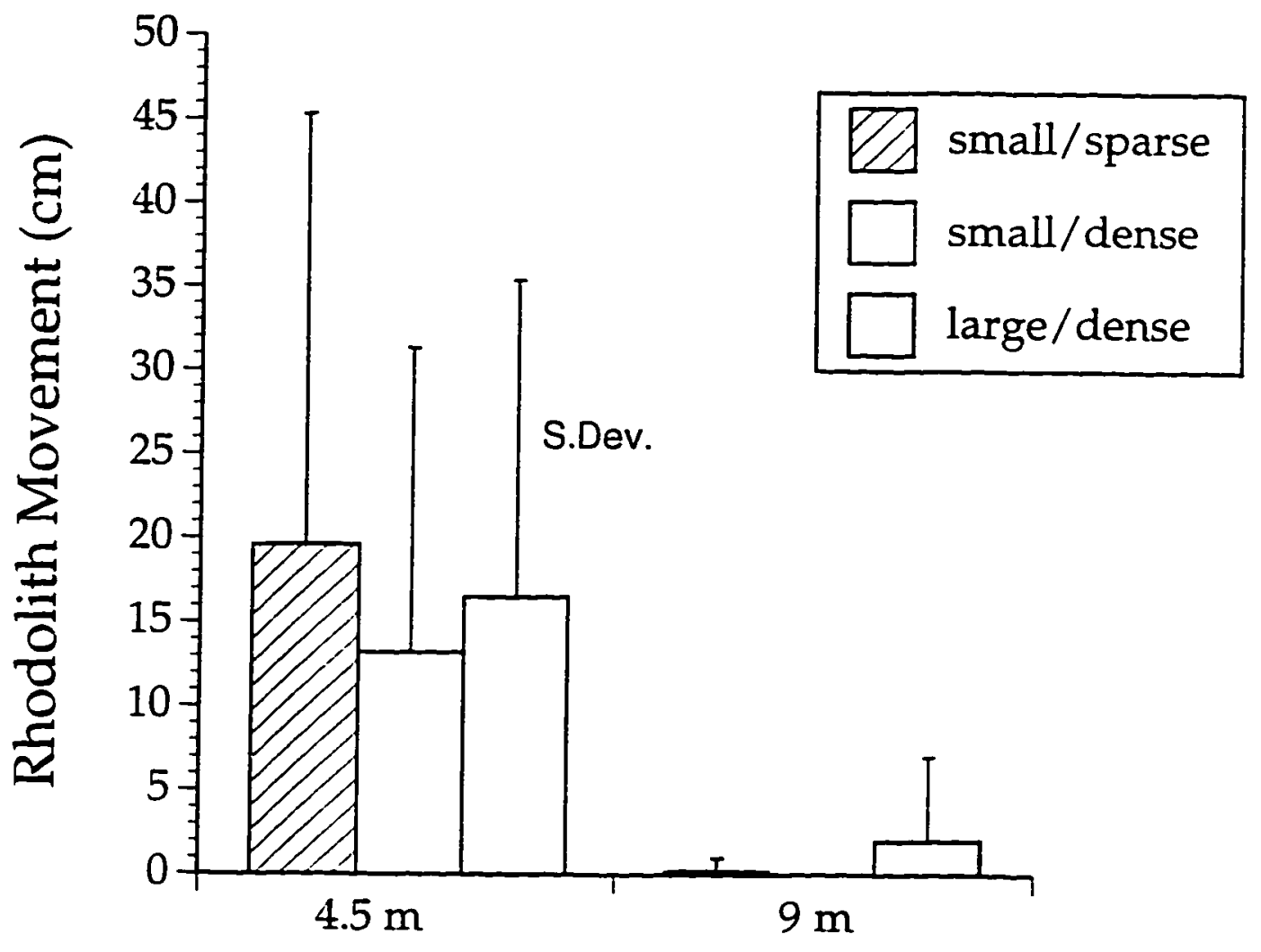

Depth

Figure 9 : The movement of rhodoliths from their initial position after high water energy at two depths in the Requeson rhodolith bed. The three forms tested were small ( $2 \mathrm{~cm}$ diameter) with sparse branching, small with dense branching, and large with dense branching. 

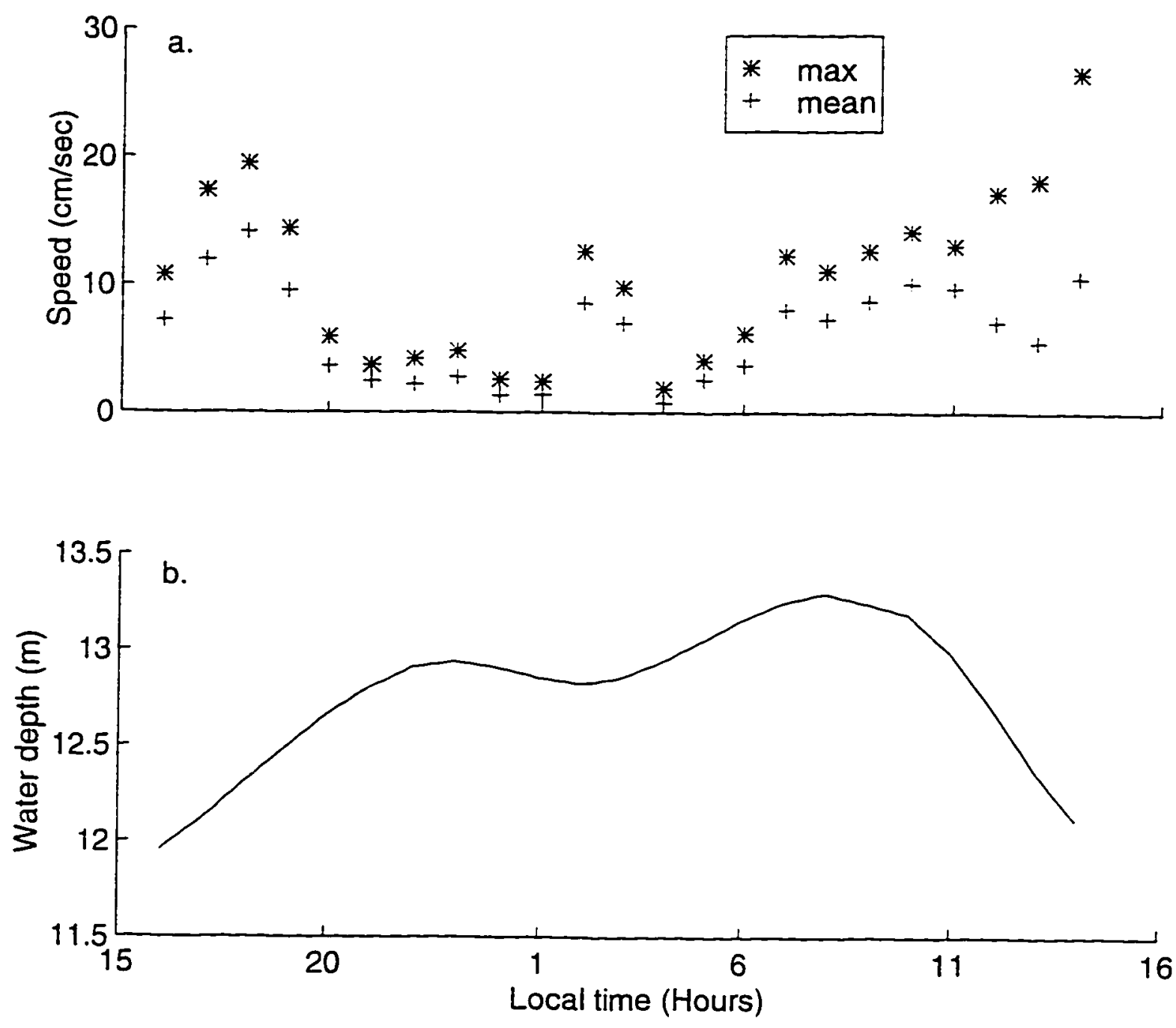

Figure 10: a) The maximum and mean current speeds from 1600 hrs. January 19. 1996 to 1400 hrs. January 20.1996 at Punta Bajo rhodolith bed measured $0.75 \mathrm{~m}$ above the seafloor at $11 \mathrm{~m}$ depth. b) Average tidal height during the same time series. For both current and tide data $\mathrm{n}=1502.0 \mathrm{sec}$ samples taken every hour. No rhodolith motion was observed. 

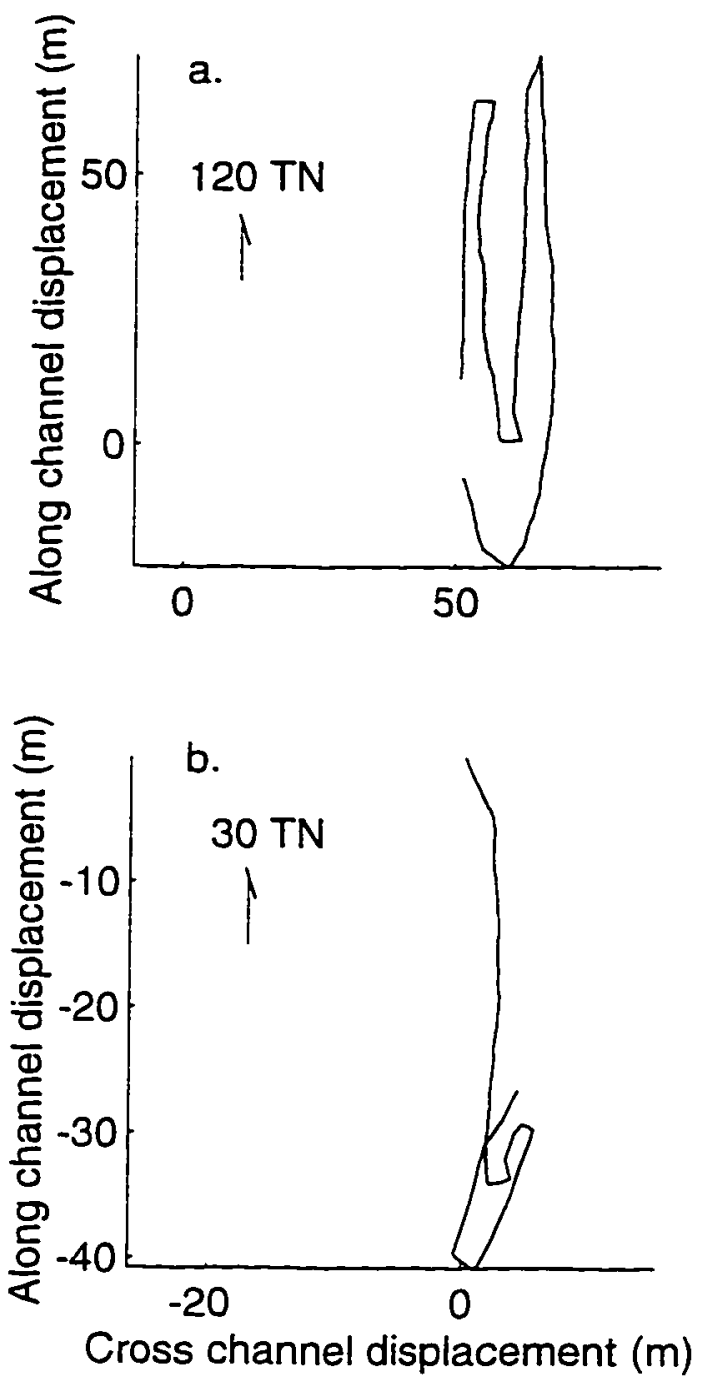

Figure 11: The cumulative displacement of water through time over rhodoliti beds in tidal channels. Directions are relative to channel so along and cross channel flow is apparent. Both records show flow reversals due to tidal switch: a) Flow through San Lorenzo Channel during February 16-17, 1996 over a 21 hour period. Flow was measured at $10 \mathrm{~m}$ depths $0.75 \mathrm{~m}$ above the rhodolith bed. b) Flow through the Punta Bajo and Isla Coronado channel during a 18 hour period from January 19-20.1996. Flow was measured at $11 \mathrm{~m}$ depths $0.75 \mathrm{~m}$ above the rhodolith beds. 

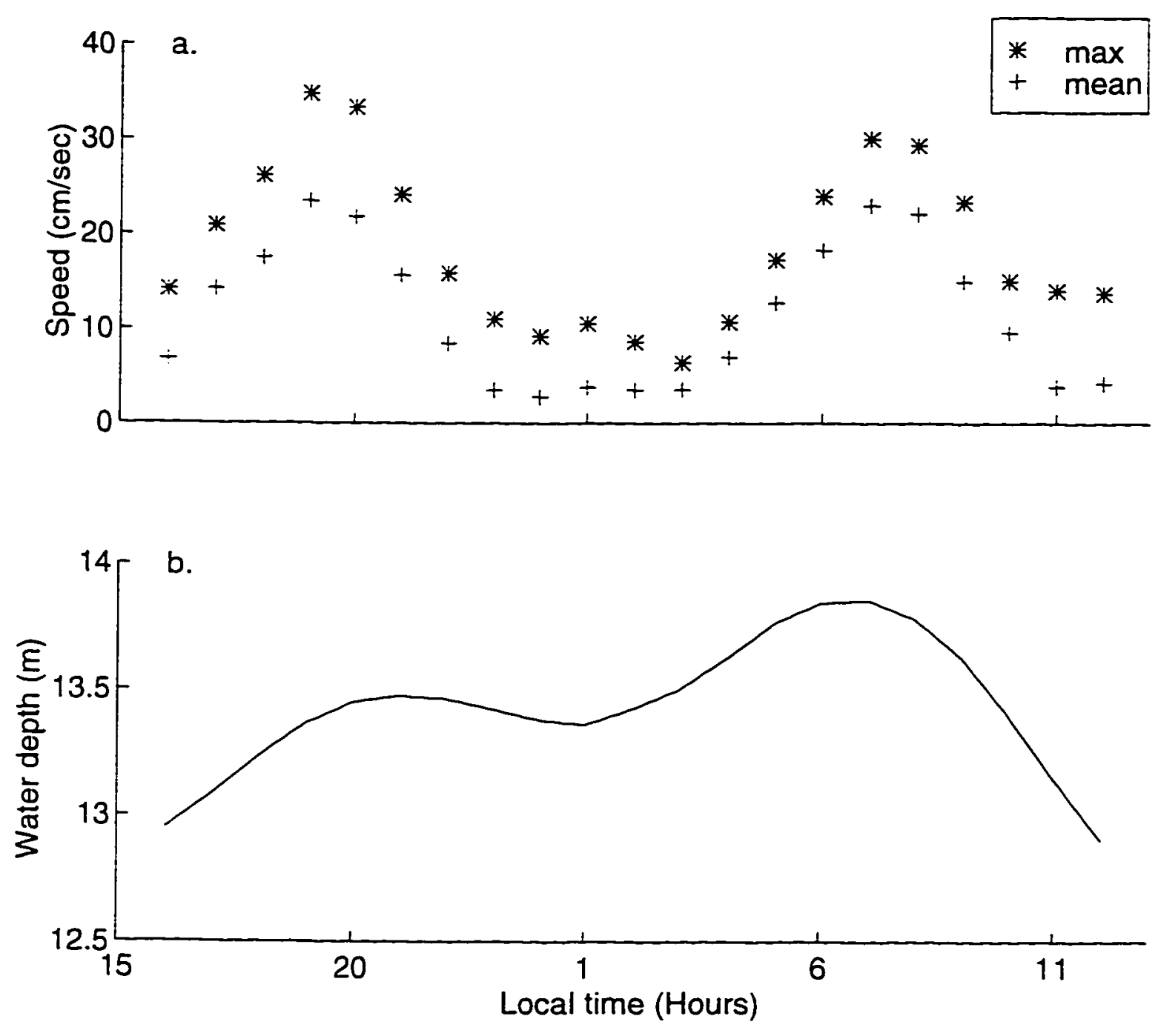

Figure 12: a) The maximum and mean current speeds from 1600 hrs. February 14. 1996 to 1200 hrs. February 15. 1996 at San Lorenzo Channel rhodolith beds measured $0.75 \mathrm{~m}$ above the seafloor at $10 \mathrm{~m}$ depth. b) Average tidal height during the same time series. For both current and tide data $\mathrm{n}=3001.0 \mathrm{sec}$ samples taken every hour. No rhodolith motion occurred. 

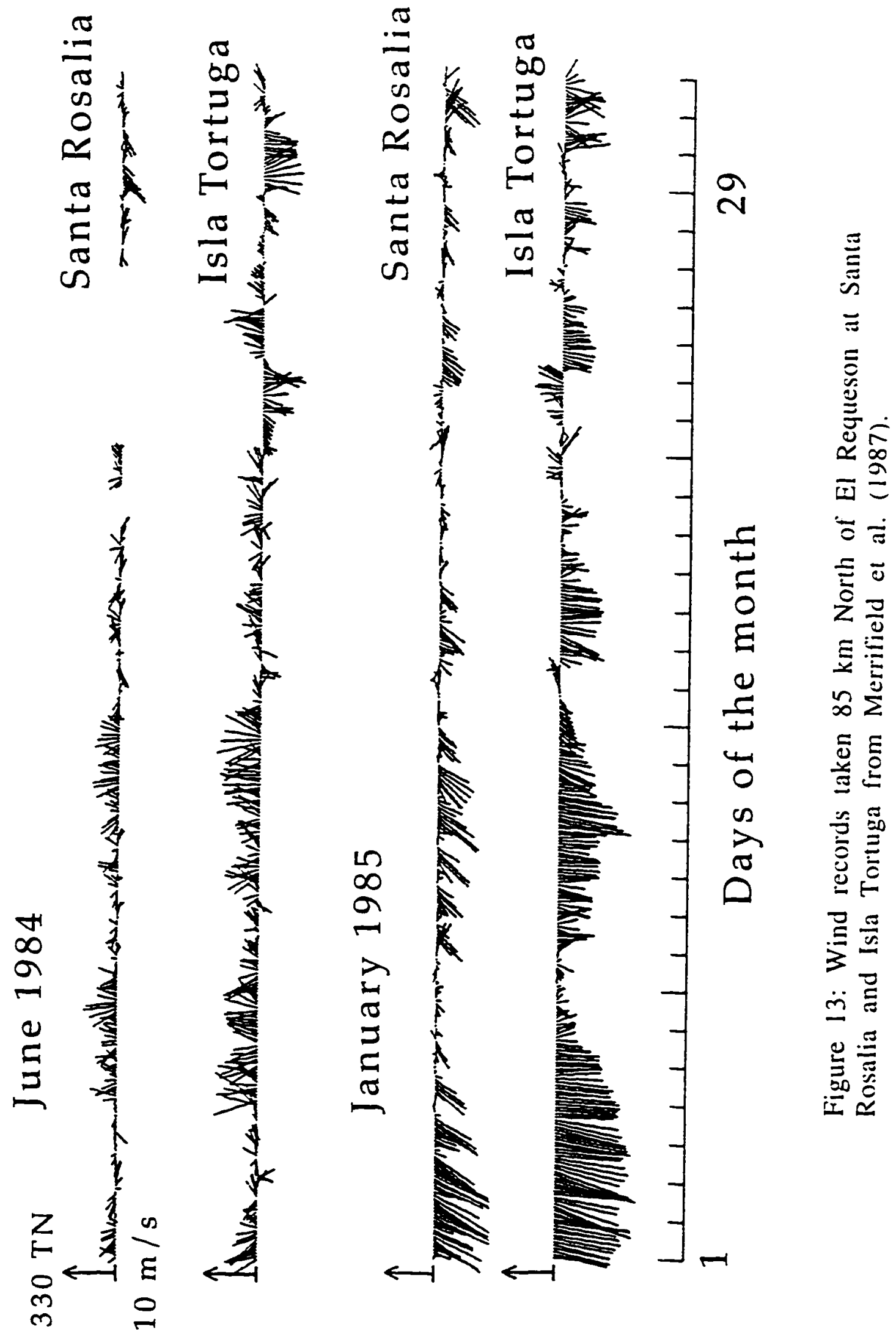


\section{Factors Affecting Transport of Rhodoliths by Water Motion}

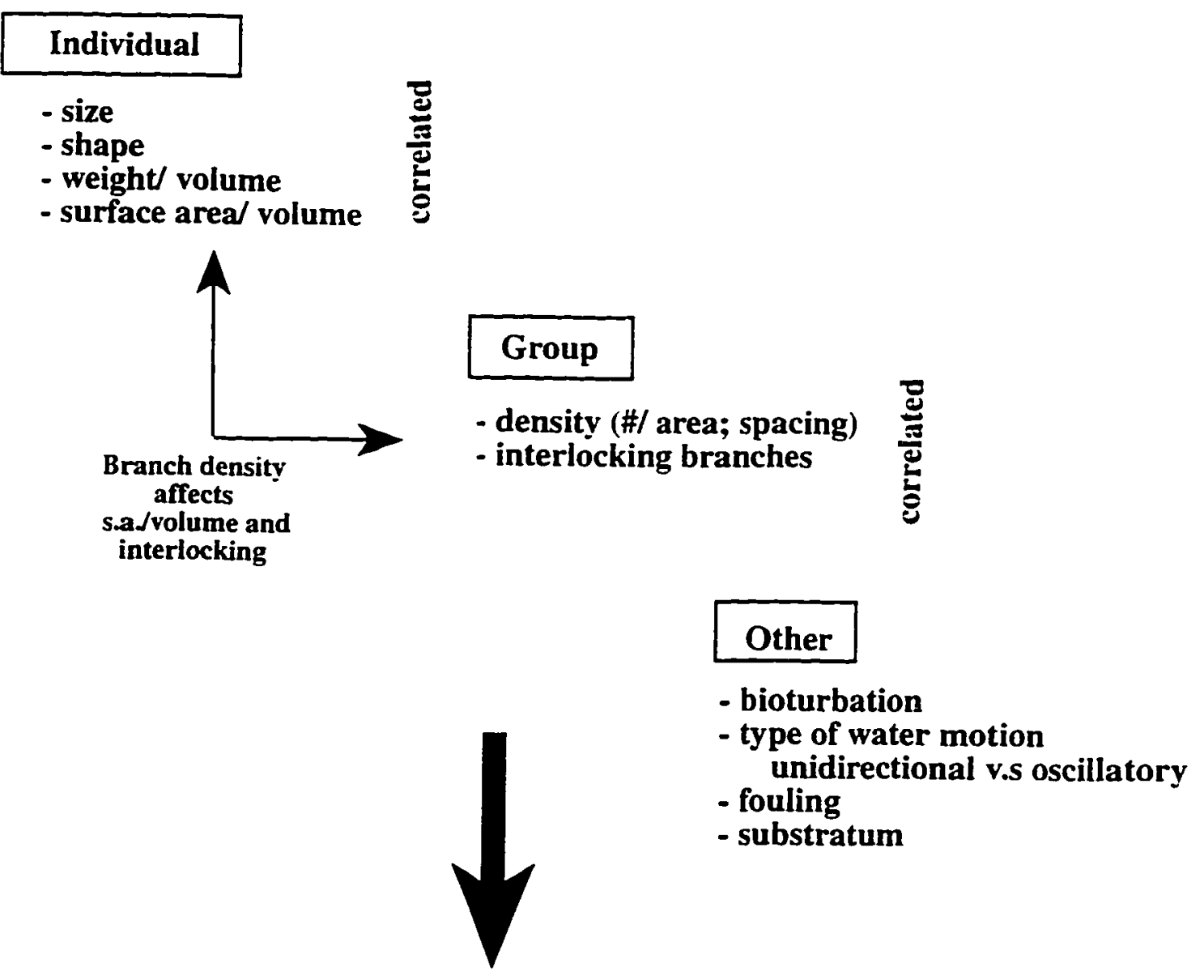

Consequences of Transport

- shape

- branch density

- branching pattern (apical/ lateral)

- "selection" for:

laminar v.s branched

foliose v.s. fruticose

species

Figure 14: Factors affecting and impacted by water motion driven rhodolith transport. 
Appendix 1: Equation to convert unidirectional current speeds to varying heights above the seabed. Equation takes the Benthic Boundary Layer into consideration (Harris and Collins 1988, Harris et al. 1996).

$$
U_{x}=\frac{\ln x-\ln z_{0}}{\ln y-\ln z_{0}} U_{y}
$$

$x, y=$ Heights above substrate

$\mathrm{U}_{\mathrm{x}}=$ Velocity at $\mathrm{x}$

$\mathrm{U}_{\mathrm{y}}=$ Velocity at $\mathrm{y}$

$z_{0}=$ Roughness length. (Estimated as the average diameter of rhodoliths divided by 30 (Smith 1977)).

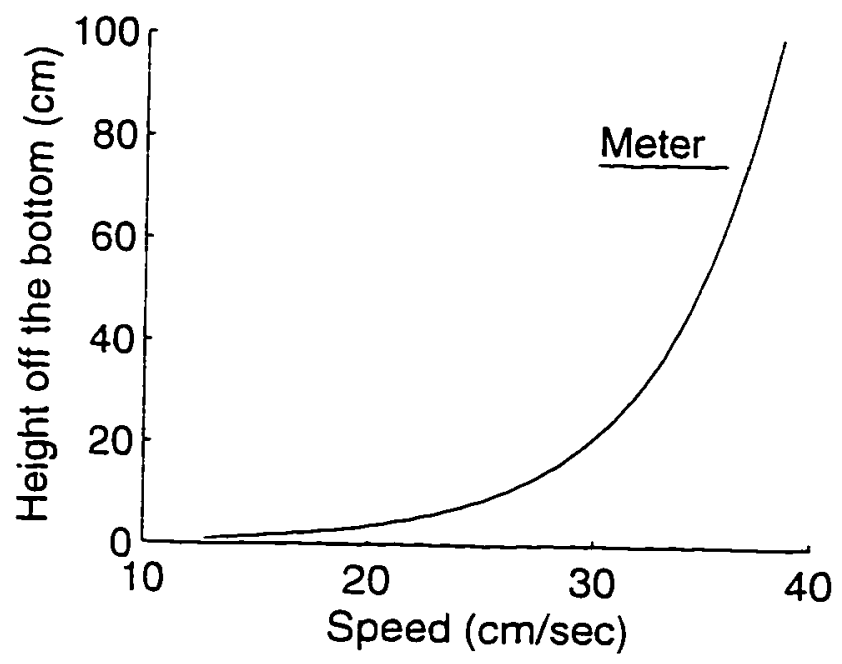


Appendix 2: Linear wave theory equations for wave length and maximum particle velocity in a wave orbital (Airy 1845, Komar 1976, Denny 1986).

$$
\begin{aligned}
& \left(\mathrm{gT}^{2}\right) \\
& \mathrm { L } = 2 \pi \longdiv { \operatorname { t a n h } ( 4 \pi ^ { 2 } \mathrm { d } / \mathrm { T } ^ { 2 } \mathrm { g } ) } \quad \mathrm { L } = \text { wave length } \\
& \mathrm{g}=\text { gravity } ;\left(9.8 \mathrm{~m} / \mathrm{sec}^{2}\right) \\
& \mathrm{d}=\text { depth below still water } \\
& \mathrm{T}=\text { wave period } \\
& U_{\max }=\frac{(\pi H)}{T} * \cos (k x-w t) * \frac{\cosh (k s)}{\sinh (k d)} \\
& \mathrm{U}_{\max }=\text { maximum particle velocity } \\
& \mathrm{T}=\text { wave period } \\
& \mathrm{H}=\text { wave height } \\
& \mathrm{k}=2 \pi / \mathrm{L} \\
& \mathrm{w}=2 \pi / \mathrm{T} \\
& x=\text { initial point * } \\
& \mathrm{t}=\text { time beginning* } \\
& \mathrm{s}=\text { distance from seabed }
\end{aligned}
$$

* Assume $\mathrm{x}$ and $\mathrm{t}=0$ for all calculations. 